\title{
Structural disorder of monomeric $\alpha$-synuclein persists in mammalian cells
}

Francois-Xavier Theillet, Andres Binolfi, Beata Bekei, Andrea Martorana, Honor May Rose, Marchel Stuiver, Silvia Verzini, Dorothea Lorenz, Marleen van Rossum, Daniella Goldfarb \& Philipp Selenko

DOI: https://doi.org/10.1038/nature16531

Original publication date: 25 January 2016

Document version: Author's accepted manuscript version

Published in: Nature (ISSN: 1476-4687)

\section{Cite as:}

Theillet, Francois-Xavier; Binolfi, Andres; Bekei, Beata; Martorana, Andrea; Rose, Honor May; Stuiver, Marchel; Verzini, Silvia; Lorenz, Dorothea; van Rossum, Marleen; Goldfarb, Daniella; Selenko, Philipp (2016) Structural disorder of monomeric $\alpha$-synuclein persists in mammalian cells. Nature 530:45-50. 


\section{Structural disorder of monomeric $\alpha$-synuclein persists in mammalian cells}

Francois-Xavier Theillet ${ }^{1,4^{*}}$, Andres Binolfi ${ }^{1,5^{*}}$, Beata Bekei ${ }^{*}$, Andrea Martorana ${ }^{2}$, Honor May Rose ${ }^{1}$, Marchel Stuiver ${ }^{1}$, Silvia Verzini ${ }^{1}$, Dorothea Lorenz ${ }^{3}$, Marleen van Rossum $^{1}$, Daniella Goldfarb ${ }^{2}$ and Philipp Selenko ${ }^{1}$

${ }^{1}$ In-Cell NMR Laboratory, Department of NMR-supported Structural Biology and ${ }^{3}$ Department of Molecular Physiology and Cell Biology

Leibniz Institute of Molecular Pharmacology (FMP Berlin)

Robert-Rössle Strasse 10, 13125 Berlin, Germany

${ }^{2}$ Department of Chemical Physics, Weizmann Institute of Science, Rehovot, 76100 Israel

${ }^{4}$ present address: Department of Biochemistry, Biophysics and Structural Biology, Institute for Integrative Biology of the Cell (I2BC), UMR9198 CNRS, Bât 144, CEA Saclay, 91191 Gif-sur-Yvette, France

${ }^{5}$ present address: Max Planck Laboratory for Structural Biology, Chemistry and Molecular Biophysics of Rosario (MPLbioR-UNR) and Instituto de Investigaciones para el Descubrimiento de Fármacos de Rosario (IIDEFAR-CONICET), 27 de Febrero 210 bis; S2002LRK-Rosario, Argentina

\footnotetext{
* these authors contributed equally

corresponding author: selenko@,fmp-berlin.de
} 


\section{Summary}

Intracellular aggregation of the human amyloid protein $\alpha$-synuclein is causally linked to Parkinson's disease. While the isolated protein is intrinsically disordered, its native structure in mammalian cells is not known. Here, we use nuclear magnetic resonance (NMR) and electron paramagnetic resonance (EPR) spectroscopy to derive atomicresolution insights into the structure and dynamics of $\alpha$-synuclein in different mammalian cell types. We show that the disordered nature of monomeric $\alpha$-synuclein is stably preserved in non-neuronal and neuronal cells. Under physiological cell conditions, $\alpha$-synuclein is $\mathrm{N}$-terminally acetylated and adopts conformations that are more compact than in buffer, with residues of the aggregation-prone non-amyloid $\beta$ component (NAC) region shielded from exposure to the cytoplasm, which likely counteracts spontaneous aggregation. These results establish that different types of crowded intracellular environments do not inherently promote $\alpha$-synuclein oligomerization and, more generally, that intrinsic structural disorder is sustainable in mammalian cells. 


\section{Main Text}

The impact of the crowded intracellular environment on the structure and dynamics of proteins is poorly understood, which is particularly evident for proteins that lack folded structures in the absence of binding partners, i.e. intrinsically disordered proteins (IDPs) ${ }^{1}$. Human $\alpha$-synuclein $(\alpha$ Syn) represents a prototypic IDP whose notoriety is directly linked to its role as the primary protein component of amyloid deposits in the brains of Parkinson's disease patients (termed Lewy bodies) and in individuals with other synucleinopathies ${ }^{2}$. While $\alpha$ Syn is abundantly expressed throughout the brain ${ }^{3}$, amyloid aggregates are primarily found in remnants of apoptotic dopaminergic neurons of the substantia nigra ${ }^{4}$. This raises the possibility that $\alpha$ Syn adopts different structures in different types of neuronal cells and that these structures exhibit different aggregation propensities ${ }^{5}$. In this light, recent reports postulate that $\alpha$ Syn principally exists as a folded helical tetramer in intact prokaryotic and eukaryotic cells ${ }^{6,7}$. Although subsequently challenged in several follow-up studies $^{8-11}$, as well as progressively adjusted by the proponents of the initial hypothesis $^{12-14}$, the monomer-tetramer controversy remains at the heart of ongoing discussions about the native structural state(s) of $\alpha$ Syn in mammalian cells ${ }^{15}$. To answer this question is key for our understanding of possible mechanisms of amyloid formation, not only in the case of aSyn and Parkinson's disease, but also for the plethora of other neurodegenerative disorders involving $\operatorname{IDPs}^{16}$.

\section{$\alpha$ Syn is disordered in mammalian cells}

To obtain atomic-resolution insights into the structure and dynamics of $\alpha$ Syn in mammalian cells, we set out to perform in-cell NMR experiments in non-neuronal A2780 and HeLa, and neuronal B65, SK-N-SH and RCSN-3 cells, the latter being 
directly derived from rat substantia nigra neurons ${ }^{17}$. To generate in-cell NMR samples in the physiological concentration range of endogenous $\alpha$ Syn in primary neurons, i.e. 5-50 $\mu \mathrm{M}^{3,18}$, we developed a simple electroporation protocol to deliver defined amounts of isotope-enriched $\alpha$ Syn into cultured mammalian cells (Fig. 1a). To ensure the physiological intactness of our in-cell NMR samples, we assessed cell viability by flow cytometry (FCM) and used immunofluorescence (IF) and electron microscopy (EM) to establish that delivered $\alpha$ Syn distributed evenly throughout the cytoplasm of electroporated cells (Fig. 1b and Extended Data Fig. 1a, b). In line with previous findings, we measured an intracellular protein half-life of $\sim 50$ hours ${ }^{19}$ without significant changes in cytoplasmic $\alpha$ Syn staining (Fig. 1c). To correlate the effective NMR concentrations of isotope-enriched $\alpha$ Syn in the different cell samples to concentrations that we determined by semi-quantitative Western blotting, we recorded one-dimensional (1D) ${ }^{15} \mathrm{~N}$-filtered in-cell NMR spectra on all specimens (Fig. 2a and Extended Data Fig. 1c). Amide envelope intensity matching verified that $90 \pm 10 \%$ of delivered $\alpha$ Syn molecules contributed to the measured in-cell NMR signals $\left(S_{\text {eff }}\right)$, demonstrating that exogenously delivered $\alpha$ Syn tumbled freely in the cytoplasm of electroporated cells and did not stably interact with large cellular structures such as membranes. Cell viability and leakage tests after in-cell NMR experiments ruled out signal contributions from external $\alpha$ Syn (Extended Data Fig. 1d, e).

Residue-resolved two-dimensional (2D) ${ }^{1} \mathrm{H}^{-15} \mathrm{~N}$ in-cell NMR spectra of $\alpha$ Syn in A2780, HeLa, RCSN-3, B65 and SK-N-SH cells displayed strong similarities with the disordered reference state of the isolated protein, with average backbone amide chemical shift changes $(\Delta \delta)$ smaller than 0.01 p.p.m. (Fig. 2b and Extended Data Fig. 1f). These results showed that the different intracellular environments did not 
induce major conformational rearrangements of monomeric $\alpha$ Syn. We detected varying degrees of NMR signal broadening in the N- and C-terminus of $\alpha$ Syn, which were highly reproducible in replicate in-cell NMR samples (Extended Data Fig. 2).

\section{$\alpha$ Syn is N-terminally acetylated in cells}

All in-cell NMR spectra exhibited reduced signal intensities of the first ten residues of $\alpha$ Syn with peak positions that closely matched those of the N-terminally acetylated protein (Fig. 2c and Extended Data Fig. 3a). Cell lysis obliterated the observed line-broadening effects and clearly revealed the spectral features of $\mathrm{N}$ terminal acetylation (Extended Data Fig. 3b). In further support of the soluble nature of intracellular $\alpha$ Syn, we quantitatively recovered the monomeric protein in the cytoplasmic fractions of in-cell NMR sample lysates (Extended Data Fig. 3c). Having used electroporation to deliver recombinantly produced, non-acetylated $\alpha$ Syn into mammalian cells, we reasoned that $\mathrm{N}$-terminal acetylation must have occurred post-translationally. This conclusion challenges the prevalent view that $\mathrm{N}$-terminal acetylation of eukaryotic proteins is established in an exclusive co-translational manner, when nascent polypetides exit the ribosome ${ }^{20}$. Our findings further confirm that $\mathrm{N}$-terminally acetylated $\alpha$ Syn represents the physiological form of the protein, in line with previous reports ${ }^{6,10}$. As observed before, acetylation led to higher levels of residual helicity within the N-terminus of $\alpha \operatorname{Syn}^{21,22}$ and to avid binding of small unilamellar vesicles (SUVs) that we reconstituted from pig brain polar lipids (Extended Data Fig. 4a, b). Irrespective of N-terminal acetylation though, in-cell NMR experiments did not reveal the spectral features of fully membrane-associated $\alpha$ Syn, such as uniform signal broadening of its first $\sim 100$ residues $^{22,23}$, thus ruling out stable membrane interactions. 


\section{$\alpha$ Syn interacts with the cytoplasm}

To characterize the dynamic properties of acetylated $\alpha$ Syn in the different intracellular environments, we measured in-cell NMR peak intensity changes and backbone amide relaxation parameters in A2780 and SK-N-SH cells (Extended Data Fig. 4c-e) and in artificially crowded solutions containing Ficoll, BSA, lysozyme, SUVs or urea (Extended Data Fig. 5). In cells, signal attenuations primarily affected $\mathrm{N}$ - and C-terminal $\alpha$ Syn residues, whereas a biologically inert crowding agent such as Ficoll did not recapitulate these line-broadening effects (Fig. 3a). Addition of BSA or lysozyme to N-terminally acetylated $\alpha$ Syn led to selective reductions of $\mathrm{N}$ - or Cterminal signal intensities respectively, which were reminiscent of the observed incell NMR behavior. Having obtained residue-resolved intracellular ${ }^{15} \mathrm{~N}$ relaxation data $\left(R_{1}, \quad R_{2}\right.$ and ${ }^{1} \mathrm{H}^{-15} \mathrm{~N} n O e$ 's), we separated dynamic contributions on the fast nanosecond time scale governing $\alpha$ Syn's residue-specific rotational correlation time $\left(\tau_{c}\right)$, from effects in the micro- to millisecond time range giving rise to exchange terms $\left(R_{e x}\right)$ that also reflect weak transient interactions with cytoplasmic components. Higher $\tau_{c}$ profiles reported a uniform decrease of $\alpha$ Syn dynamics in A2780 and SK$\mathrm{N}-\mathrm{SH}$ cells, and in the differently crowded in vitro environments as expected for viscosity-driven reductions in overall $\alpha$ Syn mobility ${ }^{24}$ (Fig. 3b and Extended Data Fig. 6a). By contrast, we determined non-uniform exchange contributions in A2780 and SK-N-SH cells, which were largest for the first ten residues of $\alpha$ Syn and also affected amino acids around Tyr39 and the C-terminus of the protein (Fig. 3c and Extended Data Fig. 6b). We detected similar N- or C-terminal exchange profiles with BSA (pI 4.7) or lysozyme (pI 11.35), respectively (Fig. 3c and Extended Data Fig. 6c, d). To test whether complementary electrostatic interactions with the partially 
charged $\mathrm{N}$ - and C-termini of $\alpha$ Syn gave rise to these effects, we increased the salt concentrations of BSA- and lysozyme-crowded solutions and re-determined $\alpha$ Syn's $R_{e x}$ contributions. We observed no salt effects with BSA, whereas $R_{e x}$ terms in lysozyme-crowded solutions decreased at higher salt concentrations (Fig. 3c and Extended Data Fig. 6e), suggesting that electrostatic interactions mediated $\alpha$ Syn's C-terminal exchange behavior. Suspecting alternative hydrophobic effects as the cause for exchange contributions in the N-terminus of $\alpha$ Syn, we replaced Phe 4 and Tyr39 with alanines (i.e., F4A-Y39A) and re-measured protein dynamics and $R_{e x}$ in A2780 and SK-N-SH cells, and in the presence of BSA (Fig. 3c and Extended Data Fig. 7a). We found diminished exchange contributions in vitro and in cells, which strengthened the notion that hydrophobic contacts mediate N-terminal signal attenuations independently of C-terminal interactions. Binding of N-terminally acetylated F4A-Y39A $\alpha$ Syn to sub-saturating amounts of SUVs was weaker than that of the wild-type (WT) protein and exchange terms were greatly reduced, although levels of increased residual helicity in the N-terminus of mutant $\alpha$ Syn were preserved (Fig. 3c and Extended Data Fig. 7b). These results suggested that transient membrane interactions likely contribute to $\alpha$ Syn's in-cell NMR behavior, especially with regard to hydrophobic 'membrane scanning' of N-terminal $\alpha$ Syn residues ${ }^{25}$. Because cell lysis obliterated the observed line broadening effects (Extended Data Fig. 3b), we concluded that weak hydrophobic and electrostatic interactions are not preserved under dilute extract conditions. Thus, we demonstrate that protein dynamics of monomeric $\alpha$ Syn in intact mammalian cells are governed by viscosity-driven reductions in overall mobility and by weak hydrophobic and electrostatic interactions of N- and C-terminal residues with intracellular components, respectively (Fig. 4a). Importantly, our data also revealed that the aggregation-prone non-amyloid $\beta$ 
component (NAC) region of $\alpha$ Syn experiences the least effects in the different intracellular environments, without substantial exchange contributions (Fig. 3c). While this may reflect the paucity of aromatic and charged residues in the NAC region, it may also indicate the presence of intracellular protein conformations that shield NAC residues from exposure to the cytoplasm (Fig. $\mathbf{4 b}$ ).

\section{$\alpha$ Syn adopts compact structures in cells}

To investigate whether such $\alpha$ Syn conformations exist in cells, we performed paramagnetic relaxation enhancement (PRE) and electron paramagnetic resonance (EPR), double electron-electron resonance (DEER) measurements ${ }^{26}$ on A2780 and SK-N-SH cells that we electroporated with appropriately isotope-enriched and stably maleimide DOTA-tagged and Gd(III)-loaded $\alpha$ Syn (Fig. 5a and Extended Data Fig. 8, 9a, b). Previous PRE experiments on isolated $\alpha$ Syn showed that the protein exhibits transient long-range interactions between $\mathrm{N}$ - and C-terminal residues ${ }^{27,28}$. These intramolecular contacts result in loosely packed $\alpha$ Syn structures that deviate from extended polypeptide chain conformations and occlude the central NAC region. PRE experiments on spin-labeled $\alpha$ Syn in A2780 and SK-N-SH cells revealed distance profiles that were similar to those of the isolated protein, thus arguing for the preservation of intramolecular $\alpha$ Syn contacts in intact cells (Fig. 5a and Extended

Data Fig. 8). Notably, however, in-cell PRE profiles also indicated greater levels of aSyn compaction, which suggested that both intracellular environments strengthen, rather than weaken the structural features that $\alpha$ Syn displays in buffer. PRE experiments in Ficoll- and BSA-crowded solutions $(200 \mathrm{~g} / \mathrm{L})$ recapitulated these compaction effects (Fig. 5b), whereas denaturation with $8 \mathrm{M}$ urea led to extended $\alpha$ Syn structures (Extended Data Fig. 8). Complementary DEER experiments in 
A2780 cells confirmed these results (Extended Data Fig. 9c, d). To test whether aSyn formed oligomers, or aggregates in A2780 cells, we also performed intermolecular DEER and PRE measurements ${ }^{29}$. Even at intracellular $\alpha$ Syn concentrations above $50 \mu \mathrm{M}$, neither experimental approach yielded indications for such events, although we detected sparsely populated $\alpha$ Syn oligomers in the presence of $200 \mathrm{~g} / \mathrm{L}$ of Ficoll and BSA (Extended Data Fig. 9e, f).

\section{Discussion}

Our results show that exogenously delivered $\alpha$ Syn exists as an N-terminally acetylated, disordered and highly dynamic monomer in neuronal and non-neuronal cells, without detectable signs of oligomerization, spontaneous aggregation, or targeted degradation. In the absence of chemical cross-linking ${ }^{12-14}$ and the concomitant introduction of oligomer-promoting agents such as dimethyl sulfoxide $(\mathrm{DMSO})^{30}$, monomeric $\alpha$ Syn represents the predominant species in the cytoplasm of cells analyzed in this study. Although we cannot rule out the presence of other lowly populated $\alpha$ Syn states in our in-cell NMR and EPR samples, we can exclude scenarios in which the majority of $\alpha$ Syn molecules adopts stably folded, or fully membrane-associated structures ${ }^{6,9}$. In-cell conformations of $\alpha$ Syn are generally more compact than in buffer and shield hydrophobic residues of the amyloidogenic NAC region from interactions with the cytoplasm, similar to the folding principle of structured proteins. By contrast, Phe4 and Tyr39 prominently engage in transient interactions with cytoplasmic components, whereas negatively charged residues in the C-terminus of $\alpha$-synuclein sample weak electrostatic contacts. Both types of interactions can be recapitulated in artificially crowded in vitro solutions and are lost upon cell lysis, reminiscent of previously observed quinary structure interactions of 
folded and partially disordered proteins in prokaryotic and eukaryotic cells $\mathrm{s}^{31,32}$. By exhibiting structural features that disfavor NAC-mediated interactions, large conformational rearrangements appear to be necessary for $\alpha$ Syn to oligomerize under native cell conditions ${ }^{33}$, for which the identified sampling of hydrophobic contacts by Phe4 and Tyr39, including the transient binding of cellular membranes may set the stage $^{34}$. Given that these residues are critical for $\alpha$ Syn aggregation in vitro ${ }^{35}$, they may also constitute 'interaction hotspots' in the formation of early $\alpha$ Syn oligomers in cells.

\section{References}

1. Theillet, F. X. et al. Physicochemical properties of cells and their effects on intrinsically disordered proteins (IDPs). Chem. Rev. 114, 6661-6714 (2014).

2. Goedert, M., Spillantini, M. G., Del Tredici, K. \& Braak, H. 100 years of Lewy pathology. Nat. Rev. Neurol. 9, 13-24 (2013).

3. Iwai, A. et al. The precursor protein of non-A beta component of Alzheimer's disease amyloid is a presynaptic protein of the central nervous system. Neuron 14, 467-475 (1995).

4. Lashuel, H. A., Overk, C. R., Oueslati, A. \& Masliah, E. The many faces of alpha-synuclein: from structure and toxicity to therapeutic target. Nat. Rev. Neurosci. 14, 38-48 (2013).

5. Dettmer, U., Selkoe, D. \& Bartels, T. New insights into cellular alphasynuclein homeostasis in health and disease. Curr. Opin. Neurobiol. 36, 15-22 (2015).

6. Bartels, T., Choi, J. G. \& Selkoe, D. J. alpha-Synuclein occurs physiologically as a helically folded tetramer that resists aggregation. Nature 477, 107-110 (2011). 
7. Wang, W. et al. A soluble alpha-synuclein construct forms a dynamic tetramer. Proc. Natl. Acad. Sci. U S A 108, 17797-17802 (2011).

8. Binolfi, A., Theillet, F. X. \& Selenko, P. Bacterial in-cell NMR of human alpha-synuclein: a disordered monomer by nature? Biochem. Soc. Trans. 40, 950-954 (2012).

9. Burre, J. et al. Properties of native brain alpha-synuclein. Nature 498, E4-E6 (2013).

10. Fauvet, B. et al. Characterization of semisynthetic and naturally N-alphaacetylated alpha-synuclein in vitro and in intact cells: implications for aggregation and cellular properties of alpha-synuclein. J. Biol. Chem. 287, 28243-28262 (2012).

11. Fauvet, B. et al. alpha-Synuclein in central nervous system and from erythrocytes, mammalian cells, and Escherichia coli exists predominantly as disordered monomer. J. Biol. Chem. 287, 15345-64 (2012).

12. Dettmer, U., Newman, A. J., Luth, E. S., Bartels, T. \& Selkoe, D. In vivo cross-linking reveals principally oligomeric forms of alpha-synuclein and beta-synuclein in neurons and non-neural cells. J. Biol. Chem. 288, 6371-85 (2013).

13. Dettmer, U. et al. Parkinson-causing alpha-synuclein missense mutations shift native tetramers to monomers as a mechanism for disease initiation. Nat. Commun. 6, 7314 (2015).

14. Luth, E. S., Bartels, T., Dettmer, U., Kim, N. C. \& Selkoe, D. J. Purification of alpha-synuclein from human brain reveals an instability of endogenous multimers as the protein approaches purity. Biochemistry 54, 279-292 (2015). 
15. Selkoe, D. et al. Defining the native state of alpha-synuclein. Neurodegener. Dis. 13, 114-117 (2014).

16. Uversky, V. N. Intrinsically disordered proteins and their (disordered) proteomes in neurodegenerative disorders. Front. Aging Neurosci. 7, 18 (2015).

17. Paris, I. et al. The catecholaminergic RCSN-3 cell line: a model to study dopamine metabolism. Neurotox. Res. 13, 221-230 (2008).

18. Wilhelm, B. G. et al. Composition of isolated synaptic boutons reveals the amounts of vesicle trafficking proteins. Science 344, 1023-1028 (2014).

19. Okochi, M. et al. Constitutive phosphorylation of the Parkinson's disease associated alpha-synuclein. J. Biol. Chem. 275, 390-397 (2000).

20. Starheim, K. K., Gevaert, K. \& Arnesen, T. Protein N-terminal acetyltransferases: when the start matters. Trends Biochem. Sci. 37, 152-161 (2012).

21. Kang, L. J. et al. N-terminal acetylation of alpha-synuclein induces increased transient helical propensity and decreased aggregation rates in the intrinsically disordered monomer. Protein Sci. 21, 911-917 (2012).

22. Maltsev, A. S., Ying, J. F. \& Bax, A. Impact of N-terminal acetylation of alpha-synuclein on its random coil and lipid binding properties. Biochemistry 51, 5004-5013 (2012).

23. Dikiy, I. \& Eliezer, D. N-terminal acetylation stabilizes N-terminal helicity in lipid- and micelle-bound alpha-synuclein and increases its affinity for physiological membranes. J. Biol. Chem. 289, 3652-3665 (2014). 
24. Li, C. G. et al. Differential dynamical effects of macromolecular crowding on an intrinsically disordered protein and a globular protein: Implications for incell NMR spectroscopy. J. Am. Chem. Soc. 130, 6310-6311 (2008).

25. Fusco, G. et al. Direct observation of the three regions in alpha-synuclein that determine its membrane-bound behaviour. Nat. Commun. 5, 3827 (2014).

26. Martorana, A. et al. Probing protein conformation in cells by EPR distance measurements using Gd3+ spin labelling. J. Am. Chem. Soc. 136, 1345813465 (2014).

27. Bertoncini, C. W. et al. Release of long-range tertiary interactions potentiates aggregation of natively unstructured alpha-synuclein. Proc. Natl. Acad. Sci. U $S A$ 102, 1430-1435 (2005).

28. Dedmon, M. M., Lindorff-Larsen, K., Christodoulou, J., Vendruscolo, M. \& Dobson, C. M. Mapping long-range interactions in alpha-synuclein using spinlabel NMR and ensemble molecular dynamics simulations. J. Am. Chem. Soc. 127, 476-477 (2005).

29. Wu, K. P. \& Baum, J. Detection of transient interchain interactions in the intrinsically disordered protein alpha-synuclein by NMR paramagnetic relaxation enhancement. J. Am. Chem. Soc. 132, 5546-5547 (2010).

30. Kostka, M. et al. Single particle characterization of iron-induced pore-forming alpha-synuclein oligomers. J. Biol. Chem. 283, 10992-11003 (2008).

31. Danielsson, J. et al. Thermodynamics of protein destabilization in live cells. Proc. Natl. Acad. Sci. U S A 112, 12402-12407 (2015).

32. Monteith, W. B., Cohen, R. D., Smith, A. E., Guzman-Cisneros, E. \& Pielak, G. J. Quinary structure modulates protein stability in cells. Proc. Natl. Acad. Sci. U S A 112, 1739-1742 (2015). 
33. Cremades, N. et al. Direct observation of the interconversion of normal and toxic forms of alpha-synuclein. Cell 149, 1048-1059 (2012).

34. Galvagnion, C. et al. Lipid vesicles trigger alpha-synuclein aggregation by stimulating primary nucleation. Nat. Chem. Biol. 11, 229-234 (2015).

35. Lamberto, G. R. et al. Structural and mechanistic basis behind the inhibitory interaction of PcTS on alpha-synuclein amyloid fibril formation. Proc. Natl. Acad. Sci. U S A 106, 21057-21062 (2009). 


\section{Figure Legends}

Figure 1: Delivery of $\alpha$ Syn into mammalian cells. (a) Electroporation (EP) of ${ }^{15} \mathrm{~N}$ isotope-enriched $\alpha$ Syn into A2780, HeLa, RCSN-3, B65 and SK-N-SH cells delivers 'NMR-visible' protein into 'NMR-invisible' intracellular environments. Western blotting confirms comparable levels of $\alpha$ Syn transduction. (b) Top panel: Flow cytometry (FCM) scatter-plots of mock (black) and Atto488- $\alpha$ Syn electroporated A2780 and SK-N-SH cells (red). Percentages of viable $\alpha$ Syn-positive (lower quadrant, x-axis) and apoptotic 7-AAD-positive cells (upper quadrant, y-axis) are indicated. Bottom panel: Immunofluorescence (IF) imaging of $\alpha$ Syn in electroporated A2780 and SK-N-SH cells (red). Actin-phalloidin staining is shown in green and DNA-DAPI in blue. Scale bar: $20 \mu \mathrm{m}$ (c) IF time-course of $\alpha$ Syn localization and stability in SK-N-SH cells 46, 70 and 94 h after electroporation. $\alpha$ Syn dilution due to cell division is compensated with higher laser power settings. Scale bar: $50 \mu \mathrm{m}$. Semiquantitative Western blotting of intracellular $\alpha$ Syn at indicated time points after EP (total number of electroporated cells loaded). Protein concentrations are determined based on a dilution series of recombinant $\alpha$ Syn. For gel source data, see

\section{Supplementary Figure 1.}


Figure 2: $\alpha$ Syn in-cell NMR samples and spectra. (a) In-cell NMR samples and schematic depiction of intracellular protein concentrations versus effective NMR concentrations. Semi-quantitative Western blotting of $\sim 10^{5}$ manipulated cells against reference amounts of recombinant $\alpha$ Syn delineates average concentrations of delivered protein per cell (calculated in molar terms based on individual cell volumes). 1D ${ }^{1} \mathrm{H}-{ }^{15} \mathrm{~N}$ NMR spectra of isotope-enriched $\alpha$ Syn in A2780 (number of cells in the receiver coil volume, $\left.N_{\text {cell }} 7 \times 10^{7}\right)$ and SK-N-SH cells $\left(N_{\text {cell }} 10 \times 10^{7}, 5\right.$ mm NMR tubes, $S_{\text {eff }}$ shown in red) and of $10 \mu \mathrm{M}$ N-terminally acetylated $\alpha$ Syn in buffer (black). 1D traces of sample supernatants (grey) confirm absence of $\alpha$ Syn leakage from electroporated cells. Bar graphs depict the comparison of intracellular $\alpha$ Syn concentrations determined by Western blotting (WB) and NMR (i.e. $[\alpha \text { Syn }]_{\text {cell, }}$ see SI Methods). Values represent the mean of two independent in-cell NMR samples ( $\alpha$ Syn concentration in EP reactions: $400 \mu \mathrm{M})$. Error bars show the range of highest and lowest values. (b) $2 \mathrm{D}{ }^{1} \mathrm{H}^{-15} \mathrm{~N}$ NMR spectra of $\alpha$ Syn in A2780 and SK-NSH cells (red, selected region) and of isolated N-terminally acetylated $\alpha$ Syn in buffer (black). N-terminal $\alpha$ Syn residues experiencing site-selective signal attenuations (boxed) are expanded in (c), with in-cell NMR contours plotted at 2.5-times lower levels (red). In-cell NMR cross-peaks superimpose with reference NMR signals of Nterminally acetylated $\alpha$ Syn in buffer (black), confirming the presence of this modification in mammalian cells. For gel source data, see Supplementary Figure 1. 
Figure 3: $\alpha$ Syn dynamics in cells and crowded solutions. (a) Residue-resolved NMR signal intensity ratios $\left(\mathrm{I} / \mathrm{I}_{0}\right)$ of $\alpha$ Syn in A2780 and SK-N-SH cells (red) identify regions of site-selective line broadening (marked with arrows). No line broadening of N-terminally acetylated $\alpha$ Syn is observed in the presence of Ficoll (blue), whereas BSA (green) and lysozyme (orange) recapitulate signal attenuations of $\mathrm{N}$ - and $\mathrm{C}$ terminal residues, respectively. Addition of sub-saturating amounts of SUVs to Nterminally acetylated $\alpha$ Syn leads to a gradual reduction of NMR signal intensities of its first 100 residues. For simplification, all profiles show values averaged over three consecutively resolved residues. (b) Residue-resolved rotational correlation time $\left(\tau_{c}\right)$ of N-terminally acetylated $\alpha$ Syn in buffer (grey), in cells (red), and in the presence of different crowding agents (averaged over three consecutively resolved residues) reveal uniform reductions of fast protein motions. (c) Site-specific exchange contributions $\left(R_{e x}\right)$ identify $\alpha$ Syn regions that engage in weak transient interactions with cytoplasmic components (marked with arrows). Substitution of Phe4 and Tyr39 with alanines (F4A-Y39A) reduces N-terminal $R_{e x}$ terms in cells (light red) and BSAcrowded solutions (light green), thus identifying hydrophobic contacts as the source of N-terminal exchange contributions. Higher salt concentrations diminish C-terminal aSyn interactions with lysozyme (light orange), arguing for electrostatic effects. Different from BSA-crowded solutions, only residues 1-20 of N-terminally acetylated aSyn exhibit pronounced exchange contributions in the presence of sub-saturating amounts of SUVs (blue), which are diminished for F4A-Y39A $\alpha$ Syn (light blue). 
Figure 4: $\alpha$ Syn interactions and conformations in cells. (a) Cartoon representation of localized hydrophobic and electrostatic interactions of $\alpha$ Syn with cytoplasmic components, shown schematically as white spheres. Hydrophobic contacts are mediated by aromatic residues Phe 4 and Tyr39 in the N-terminus of $\alpha$ Syn, whereas negatively-charged residues in the C-terminus engage in complementary electrostatic interactions with positively-charged intracellular surfaces (indicated in blue). The central NAC region (dark grey) is shielded from exposure to the cytoplasm and does not interact with intracellular components. (b) Cartoon models of possible ensemble conformations of monomeric $\alpha$ Syn in cells. 
Figure 5: Compact $\alpha$ Syn structures in cells and crowded solutions. (a) Intramolecular PRE-derived distance profiles of N-terminally acetylated $\alpha$ Syn in buffer (grey) and in A2780 and SK-N-SH cells (red). (b) Comparative PRE-derived distance profiles in Ficoll- (blue), BSA- (green) and lysozyme-crowded solutions (orange). Gd(III)-DOTA tags at residues 42 (left column) and 122 (right column) provide complementary information about $\alpha$ Syn compaction in the respective environments. Proximal PRE effects render residues adjacent to the conjugated Gd(III) invisible (red bars). PRE-derived distances were obtained assuming that every Gd(III)- ${ }^{1} \mathrm{H}$ vector fluctuation rate scales linearly with that of the backbone N-H vector and the Gd(III)-DOTA complex. For simplification, profiles show values averaged over three consecutively resolved residues. Comparisons of $\alpha$ Syn dimensions in buffer, in cells and in the presence of different crowding agents are shown on the right. Average radii of gyration and levels of $\alpha$ Syn compaction are delineated based on the scaling of representative PRE distances relative to values measured in buffer (see SI Methods). In the depicted cartoon models, residues of the NAC region are colored in dark grey. 





a

Electroporated mammalian cells

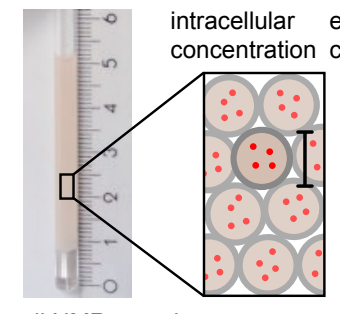

intracellular effective NMR

ation concentration

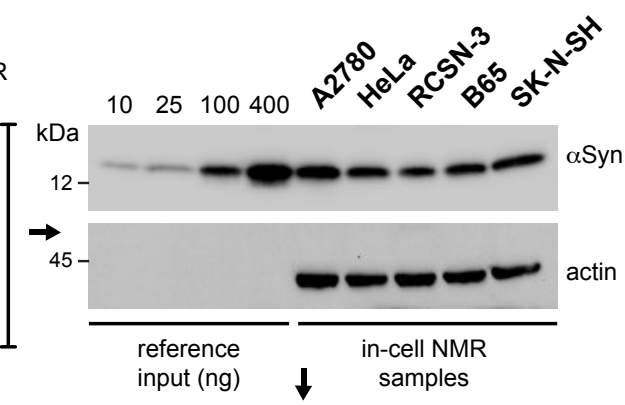

In-cell NMR sample



A2780 cells SK-N-SH cells

input (ng) $\downarrow$ samples
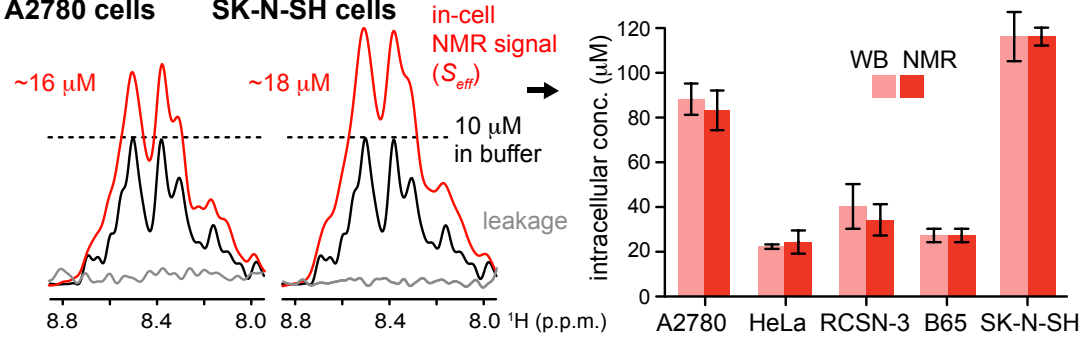

b
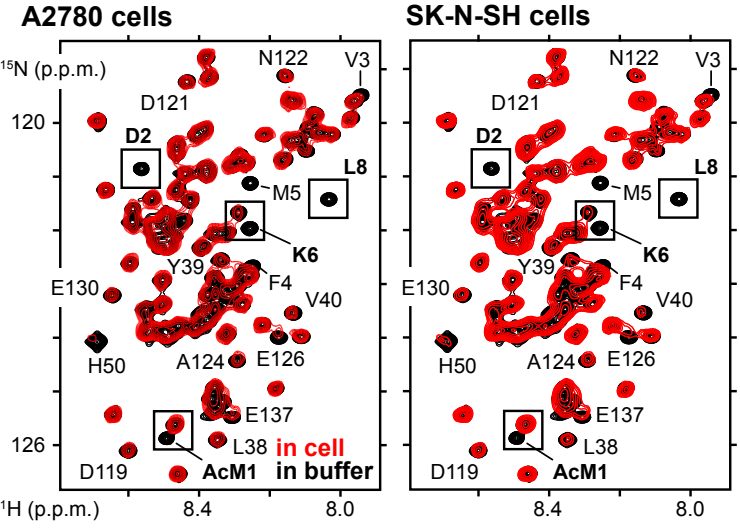

C

A2780 SK-N-SH

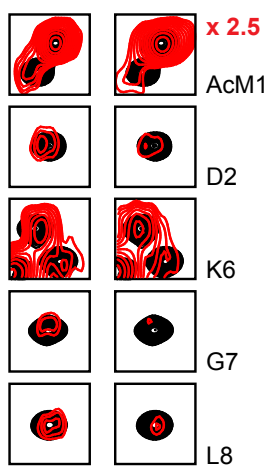


Figure 3

a

In A2780 cells
In-cell / buffer NMR peak intensities $\left(I / I_{0} \mathrm{AU}\right)$
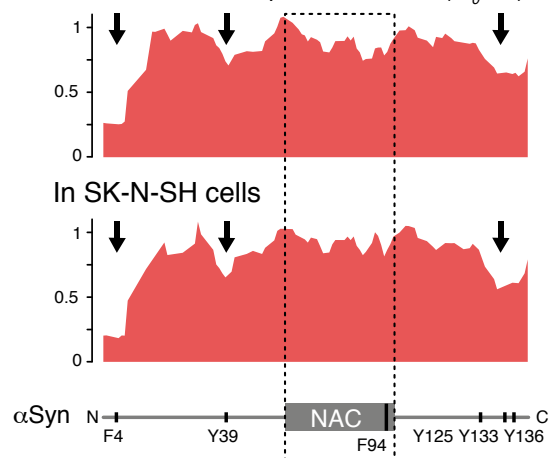

+Ficoll $\left(200 \mathrm{~g} \mathrm{l}^{-1}\right)$
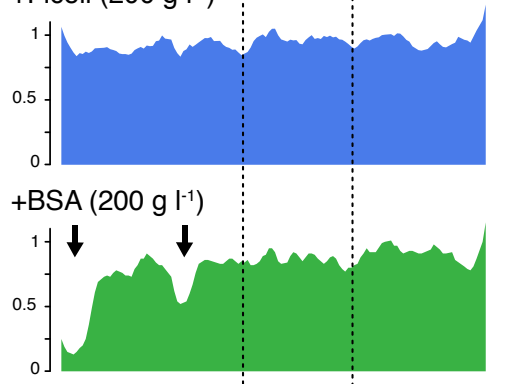

+Lysozyme $\left(10 \mathrm{~g} \mathrm{l}^{-1}\right)$

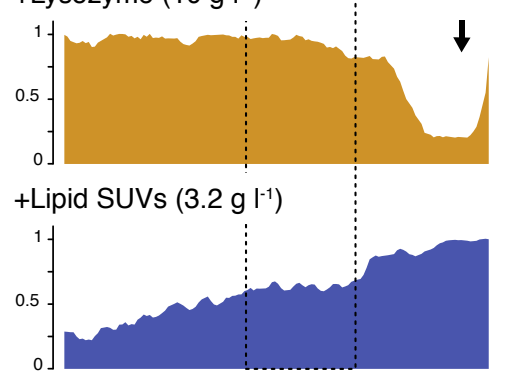

b

Mobility $\tau_{\mathrm{c}}$ (ns)
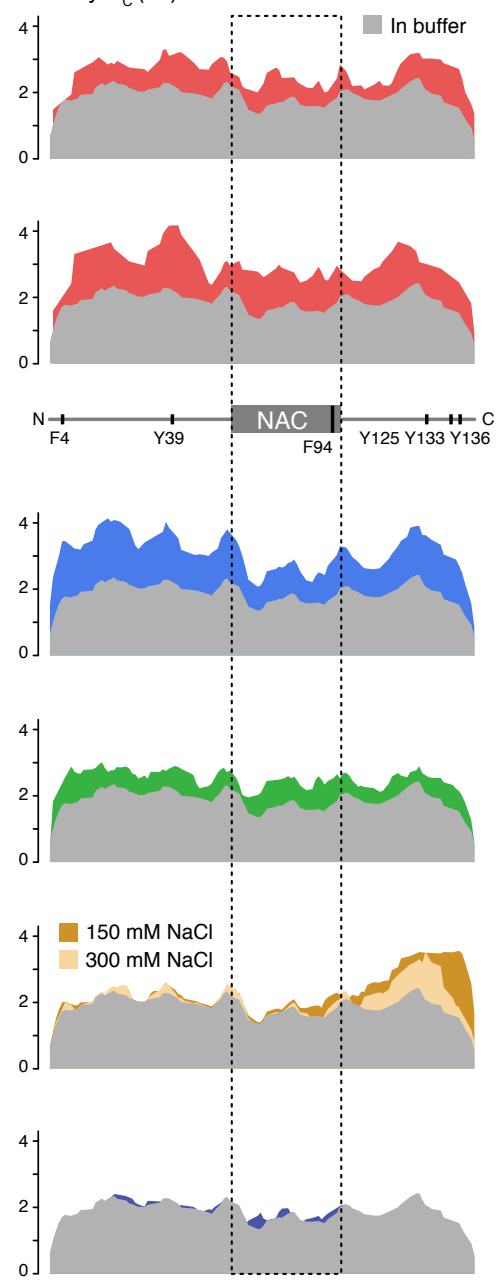

C

Exchange contributions $\mathrm{R}_{\mathrm{ex}}\left(\mathrm{s}^{-1}\right)$
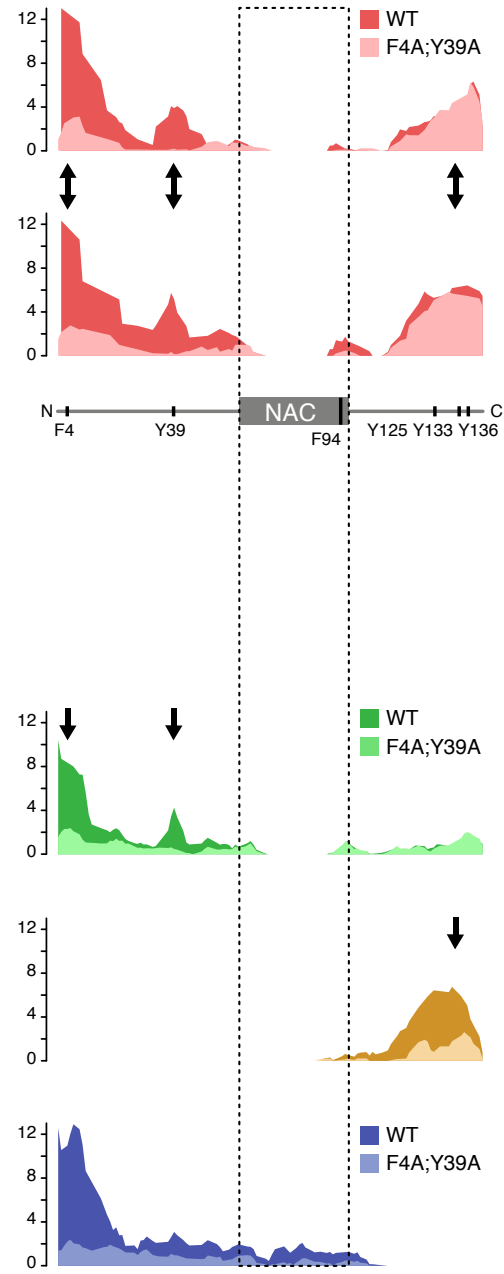
Figure 4

Theillet et al.

a

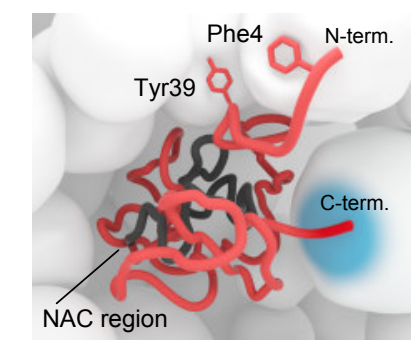

b

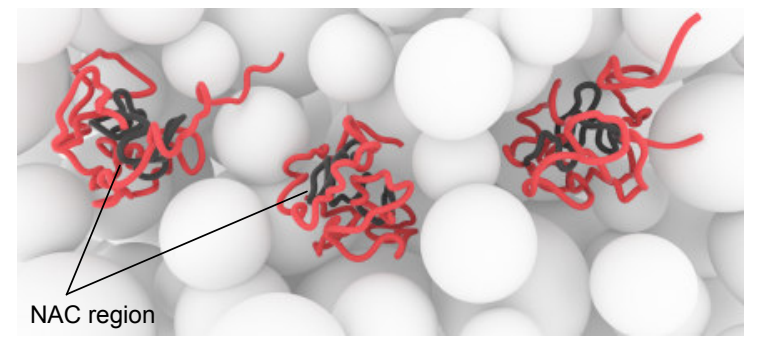


a

In A2780 cel

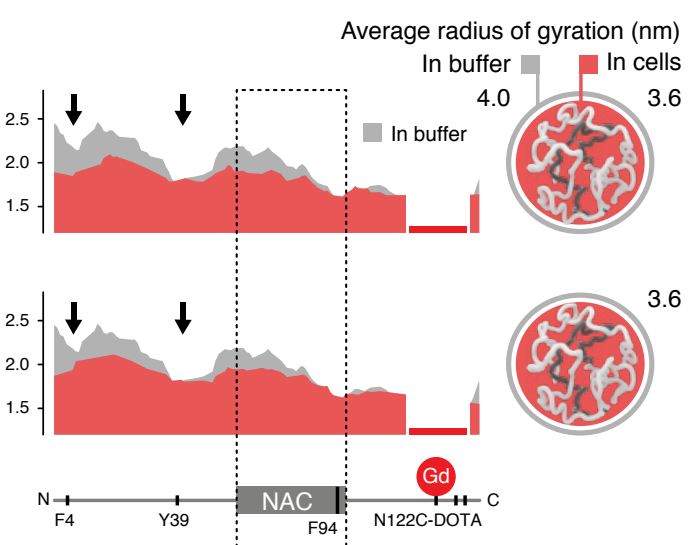

b

Intramolecular distances $<\mathrm{d}^{6}>^{1 / 6}(\mathrm{~nm})$
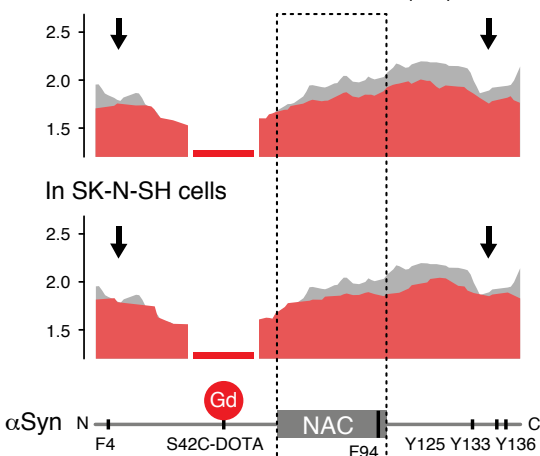

b +Ficoll $\left(200 \mathrm{~g} \mathrm{l}^{-1}\right)$

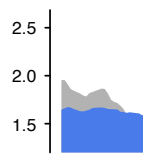

+BSA $\left(200 \mathrm{~g} \mathrm{l}^{-1}\right)$

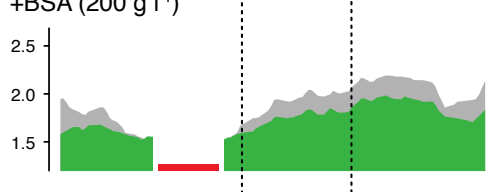

+Lysozyme $\left(10 \mathrm{~g} \mathrm{l}^{-1}\right)$
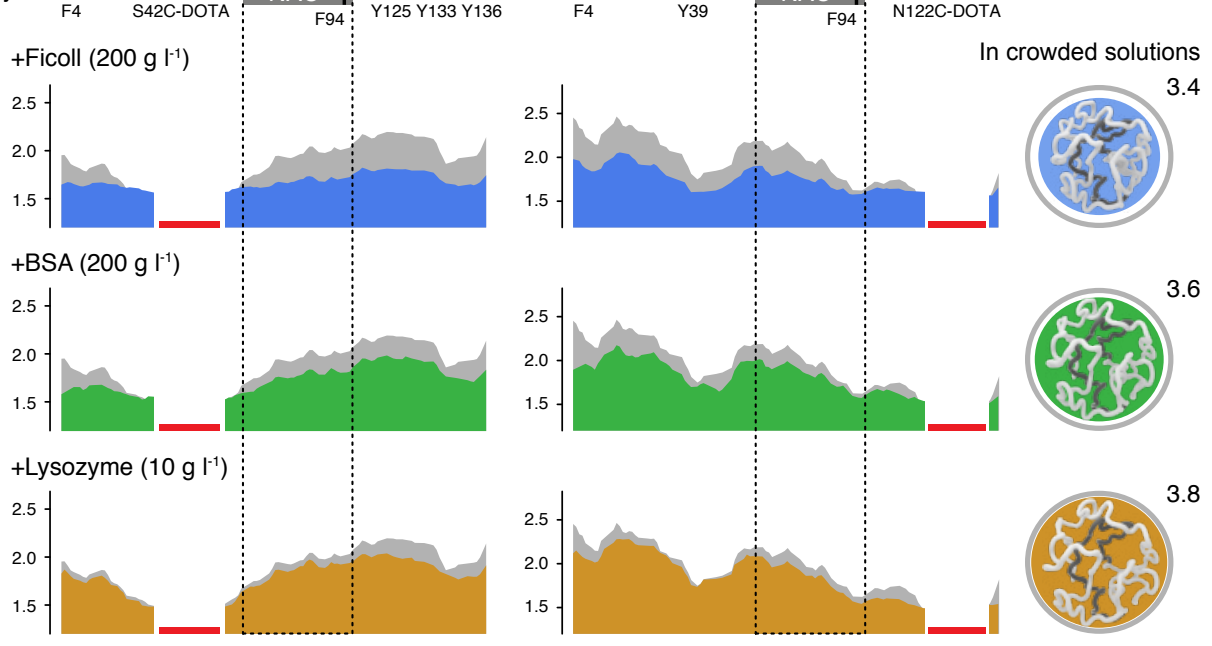


\section{Supplementary Methods}

\section{Recombinant $\alpha$ Syn}

$\alpha$ Syn was recombinantly expressed from a pT7-7 plasmid in E. coli BL21 (DE3) Express cells. To produce N-terminally acetylated $\alpha$ Syn, a plasmid encoding the yeast $\mathrm{N}$-acetyltransferase complex B (NatB) was co-overexpressed ${ }^{37}$. Non isotopeenriched $\alpha$ Syn was produced in LB medium (Sigma). ${ }^{15} \mathrm{~N}$, or ${ }^{15} \mathrm{~N}-{ }^{13} \mathrm{C}$ isotopeenriched protein (acetylated and non-acetylated) was produced in M9 minimal media supplemented with ${ }^{15} \mathrm{NH}_{4} \mathrm{Cl}(0.5 \mathrm{~g} / \mathrm{L}$, Sigma $)$ and/or $\mathrm{U}_{-}{ }^{13} \mathrm{C}$ glucose (2 g/L, Sigma), respectively. Labeled and non-labeled cultures were induced at $\mathrm{OD}_{600} 0.8$ with $1 \mathrm{mM}$ isopropyl $\beta$-D-thiogalactopyranoside (IPTG, Roth) for $\sim 12 \mathrm{~h}$ at $30{ }^{\circ} \mathrm{C}$. Monomeric $\alpha$ Syn was purified as described ${ }^{21,38}$. Purity was assessed by SDS-PAGE. Coexpression of NatB resulted in complete N-terminal acetylation of recombinant $\alpha$ Syn as confirmed by $2 \mathrm{D}{ }^{1} \mathrm{H}-{ }^{15} \mathrm{~N}$ NMR spectroscopy. $\alpha$ Syn samples were concentrated to 1-1.5 $\mathrm{mM}$ in NMR buffer (20 $\mathrm{mM}$ sodium phosphate, $150 \mathrm{mM} \mathrm{NaCl})$ at $\mathrm{pH}$ 7.0. Protein concentration was determined spectrophotometrically by UV absorption measurements at $280 \mathrm{~nm}$, with $\varepsilon: 5960 \mathrm{M}^{-1} \mathrm{~cm}^{-1}$. Final aliquots of $\alpha$ Syn stock solutions were snap frozen in liquid nitrogen and stored at $-80^{\circ} \mathrm{C}$ until use. All mutant forms of $\alpha$ Syn described in this paper were generated by site-directed mutagenesis using the QuikChange kit (Agilent Technologies) and confirmed by DNA sequencing. Recombinant protein expression and purification of $\alpha$ Syn cysteine mutants was identical to the wild-type protein except for the presence of $1 \mathrm{mM}$ dithiothreitol (DTT, Sigma) to avoid disulfide formation. 
Mammalian cell lines and media

A2780 (Sigma, cat.\# 93112519), HeLa (Sigma, cat.\# 93021013), RCSN-3

(provided by Dr. Pablo A. Caviedes, Center for Clinical Research \& Pharmacological Studies, Univ. of Chile) ${ }^{17}$, B65 (Sigma, cat.\# 85042305) and SK-N-SH cells (Sigma, cat.\# 86012802) were grown at $37{ }^{\circ} \mathrm{C}$ in humidified $5 \%(\mathrm{v} / \mathrm{v}) \mathrm{CO}_{2}$ incubators in the following media supplemented with $10 \%(\mathrm{v} / \mathrm{v})$ fetal bovine serum (FBS): RPMI 1640 for human A2780 cells; high-glucose DMEM with $10 \%$ additional FBS for rat B65 cells, low glucose DMEM for human HeLa, DMEM-Ham's F-12 for rat RCSN-3 and human SK-N-SH cells. Cells were split at 70-80 \% confluence and not passaged more than 6-12 times prior to NMR experiments. All media, supplements and phosphate buffered saline (PBS) were purchased from PAA Laboratories. All cell lines are routinely tested for mycoplasma contaminations and are mycoplasma free.

Delivery of recombinant $\alpha$ Syn into mammalian cells by electroporation (EP)

For in-cell NMR samples, $100-300 \times 10^{6}$ cells were typically used as the starting material. Cells were detached from culture flasks with trypsin/EDTA $(0.05 \%$ / $0.02 \%$ ), centrifuged at $130 \times \mathrm{g}$ for $5 \mathrm{~min}$ at $25^{\circ} \mathrm{C}$, washed once in PBS and counted on a haemocytometer. Recombinant $\alpha$ Syn was added to freshly prepared and sterile filtered electroporation buffer (EPB: $100 \mathrm{mM}$ sodium phosphate, $5 \mathrm{mM} \mathrm{KCl}, 15 \mathrm{mM}$ $\mathrm{MgCl}_{2}, 15 \mathrm{mM}$ HEPES, $2 \mathrm{mM}$ ATP (Thermo Fisher), $2 \mathrm{mM}$ reduced glutathione (Sigma) at $\mathrm{pH} 7.0$ ) to final concentrations of $200-800 \mu \mathrm{M}$. Cells were pelleted again and mixed with $\alpha$ Syn in EPB at $40 \times 10^{6}$ cells per mL. $100 \mu \mathrm{L}$ aliquots $\left(4 \times 10^{6}\right.$ cells $)$ were then transferred into $2 \mathrm{~mm}$ cuvettes and electroporated on an Amaxa Nucleofector I (Lonza). Pulse programs for the different cell lines were: \#B28 for 
A2780, HeLa and SK-N-SH cells and \#G16 for B65 and RCSN-3 cells. Cells were pulsed twice with gentle mixing in between the pulses. For control experiments, cells were mock electroporated with EPB alone. Directly after electroporation, $0.3 \mathrm{~mL}$ of pre-warmed $\left(37^{\circ} \mathrm{C}\right) \mathrm{CO}_{2}$-adjusted and cell line-matched growth medium was added to each cuvette and samples were transferred to cell culture dishes. For small-scale experiments (i.e. immunofluorescence microscopy, Western blotting, flow cytometry) aliquots of $4 \times 10^{6}$ cells were added to separate wells of a 6 -well plate $(3.5 \mathrm{~cm}$ diameter), filled with $2 \mathrm{~mL} /$ well of pre-warmed cell line-specific growth medium. For large-scale experiments (i.e. in-cell NMR and EPR), aliquots of $16-20 \times 10^{6}$ cells were added to $14 \mathrm{~cm}$ diameter dishes containing $15 \mathrm{~mL}$ of pre-warmed culture medium. Cells were returned to the incubator and allowed to recover for $5 \mathrm{~h}$. During this period, cell viability and morphology was monitored by phase-contrast microscopy. Once cells regained their adherent morphologies, dishes were washed $3 \times$ with pre-warmed PBS and cells were harvested by trypsinization. Cells were washed twice with pre-warmed PBS before further analyses. For in-cell NMR experiments, cells were taken up in 200-500 $\mu \mathrm{L}$ of pH-stable Leibovitz's L-15 medium (Life technologies), supplemented with $10 \% \mathrm{D}_{2} \mathrm{O}$ and $10 \% \mathrm{FBS}$.

\section{Western blotting (WB)}

Proteins were separated on commercial 4-18 \% gradient SDS-PAGE (BioRad), transferred onto PVDF membranes and fixed with $4 \%(\mathrm{w} / \mathrm{v})$ paraformaldehyde (PFA) in PBS for $1 \mathrm{~h}$, as described previously ${ }^{39}$. Membranes were washed $2 \times 5$ min with PBS and $2 \times 5$ min with TBS $(25 \mathrm{mM}$ Tris, $136.9 \mathrm{mM} \mathrm{NaCl}$, $2.7 \mathrm{mM} \mathrm{KCl}, \mathrm{pH}$ 7.4). After blocking for $1 \mathrm{~h}$ in $5 \%(\mathrm{w} / \mathrm{v})$ milk in TBST $(0.1 \%(\mathrm{v} / \mathrm{v})$ Tween-20 in TBS), membranes were probed with anti- $\alpha$ Syn antibody sc-69977 (Santa 
Cruz, 1:100 dilution) and anti-actin IgM (Merck Millipore, JLA20, 1:5,000 dilution). Secondary antibodies were HRP-conjugated anti-mouse or anti-rabbit (Sigma, 1:10,000 dilutions). Membranes were developed using SuperSignal West Pico or Femto chemiluminescent substrates (Thermo Scientific). Luminescence signals were detected on a BioRad Molecular Imager and quantified with ImageLab (BioRad).

Flow cytometry (FCM)

To probe intracellular $\alpha$ Syn uptake and overall cell viability by dual channel flow cytometry, cells were electroporated with Atto488-conjugated $\alpha$ Syn. To this end, N-hydroxysuccinimide (NHS) ester-activated Atto488 fluorescent dye (Sigma Aldrich) was coupled to $\alpha$ Syn lysine $\varepsilon$-amines in bicarbonate buffer at $\mathrm{pH} 8.3$ according to the manufacturer's instructions. Covalently modified $\alpha$ Syn was separated from non-reacted dye on a Sephadex G-25 column (Amersham, GE) and concentrated with $6 \mathrm{kDa}$ MW cut-off spin columns (Millipore). The final concentration of the fluorescently labeled protein was measured by UV-VIS spectrophotometry at $280 \mathrm{~nm}$ with $\varepsilon: 5690 \mathrm{M}^{-1} \mathrm{~cm}^{-1}$. A correction factor of 0.1 was subtracted to compensate for the intrinsic absorbance of the fluorophore.

Electroporation of Atto488-coupled $\alpha$ Syn was carried out with $400 \mu \mathrm{M}$ of protein and along the same procedure as for non-tagged $\alpha$ Syn. After recovery for $5 \mathrm{~h}$ in the incubator, cells were harvested and incubated with $2 \mu \mathrm{g} / \mathrm{mL}$ of 7 -AminoActinomycin D (7-AAD, Applichem) for $10 \mathrm{~min}$ at $4{ }^{\circ} \mathrm{C}$. Cells containing Atto488tagged $\alpha$ Syn $(530 \mathrm{~nm})$ and 7-AAD $(>630 \mathrm{~nm})$ were detected by dual-channel flow cytometry on a FACSCalibur (BD Biosciences, $>10,000$ recorded events for each sample). Data were analyzed with FlowJo 8.8.6 and scatter plots were generated using 
the same software. Mono-labeled samples were used to define the compensation matrix and gating thresholds. Median $\alpha$ Syn fluorescence from all events was determined with FlowJo for each sample.

\section{Immunofluorescence (IF) Microscopy}

For immunofluorescence imaging of delivered $\alpha$ Syn in fixed specimens (electroporation concentration $400 \mu \mathrm{M}$ ), cells were recovered for $5 \mathrm{~h}$ in the incubator on poly-L-lysine-coated $25 \mathrm{~mm}$ cover slips. Cells were quickly washed $3 \times$ with complete medium and treated briefly with diluted trypsin/EDTA $(0.01 \% / 0.004 \%, 40$ s, room temperature) to remove non-internalized $\alpha$ Syn, then fixed in PBS containing $4 \%(\mathrm{w} / \mathrm{v})$ PFA for $15 \mathrm{~min}$ and permeabilized with $0.1 \%(\mathrm{v} / \mathrm{v})$ Triton-X in PBS for 3 min. After washing $3 \times 10$ min with PBS, samples were blocked with $0.13 \%(\mathrm{v} / \mathrm{v})$ cold fish skin gelatin (Sigma) in PBS for $1 \mathrm{~h}$. Cells were incubated for $2 \mathrm{~h}$ with anti$\alpha$ Syn sc-69977 (Santa Cruz, 1:100 dilution) in blocking buffer. After washing $3 \times 10$ min with PBS, specimens were incubated with anti-mouse IgG Atto647, (Sigma, 1:1,000 dilution) and fluorescein isothiocyanate (FITC)-labeled phalloidin (Millipore, $2 \mu \mathrm{g} / \mathrm{mL}$ ) for $1 \mathrm{~h}$ in blocking buffer. Slides were washed $3 \times 10 \mathrm{~min}$ with PBS and nuclei stained with $1 \mu \mathrm{g} / \mathrm{mL}$ 4',6-diamidino-2-phenylindole (DAPI, Invitrogen) in PBS for 15 min. After washing once in PBS, samples were mounted with ImmuMount (Thermo Scientific). Confocal images were taken at $100 \times$ magnification and using excitation wavelengths of 405, 488, and $633 \mathrm{~nm}$ on a Zeiss LSM 510 META laser-scanning microscope. 


\section{Time-course imaging and Western blotting}

To determine the intracellular lifetime and cellular localization of delivered $\alpha$ Syn, time-course imaging experiments were performed on SK-N-SH cells electroporated with $500 \mu \mathrm{M}$ of $\alpha$ Syn as described above. After $5 \mathrm{~h}$ recovery in the incubator, cells were washed $3 \times$ with complete medium, twice with PBS, and trypsinized. Electroporated cells were divided in four equal portions, transferred onto poly-L-lysine-coated glass coverslips and returned to the incubator. At either 22, 46, 70, or 94 h post electroporation, coverslips were quickly washed once with complete medium and $3 \times$ with PBS, fixed for $15 \mathrm{~min}$ in $4 \%(\mathrm{w} / \mathrm{v})$ PFA in PBS, washed with PBS and stored in PBS at $4{ }^{\circ} \mathrm{C}$ until sampling was finished. Permeabilization, immunofluorescence staining of the fixed specimens, and confocal imaging were done in parallel and as described above. Complementary Western blot experiments were used to quantify intracellular $\alpha$ Syn levels. Specifically, SK-N-SH cells, electroporated as described above for time-course imaging were trypsinized and divided in five portions after $5 \mathrm{~h}$ of recovery. The first portion was immediately boiled in 1x Laemmli sample buffer (i.e. $5 \mathrm{~h}$ post electroporation) as described above and stored at $-20{ }^{\circ} \mathrm{C}$ until use. The other portions were re-seeded, making sure to avoid confluence over time. After 22, 46, 70, and $94 \mathrm{~h}$ post electroporation, individual portions were collected by trypsinization and processed as described for the first portion. Samples, each originating from $0.025 \times 10^{6}$ electroporated cells, thereby correcting for protein dilution due to cell division, were run on an SDS-PAGE. Immunoblotting against $\alpha$ Syn and chemiluminescence quantification as described above allowed the calculation of the protein's half-life by exponential regression 
analysis, using the algorithm provided by the doubling time online calculator website (Roth V. 2006, http://www.doubling-time.com/compute.php).

\section{Immunogold-labeling transmission electron microscopy (EM)}

To probe for organelle intactness and intracellular $\alpha$ Syn localization, $400 \mu \mathrm{M}$ of unlabeled protein was electroporated into HeLa and RCSN-3 cells. Mock samples were prepared by electroporating EPB without protein. After recovery, cells were fixed with $4 \%(\mathrm{w} / \mathrm{v})$ PFA and $0.2 \%(\mathrm{w} / \mathrm{v})$ glutaraldehyde in PBS for $1.5 \mathrm{~h}$ and washed $5 \times$ with PBS. Free aldehydes were finally quenched with $100 \mathrm{mM}$ glycine in PBS. Cells were scraped off culture dishes, centrifuged at 3,500 $\times \mathrm{g}$ for $5 \mathrm{~min}$ and cell pellets were treated with $1.8 \mathrm{M}$ glucose and $20 \%$ polyvinylpyrrolidone (Fluka) for 5 h at $37{ }^{\circ} \mathrm{C}$ for cryoprotection. $5 \mu \mathrm{L}$ aliquots were mounted onto sample holder pins and plunge frozen in liquid propane. Ultrathin cryosections $(60 \mathrm{~nm})$ were obtained with a cryo-ultramicrotome (EM FC6, Leica Microsystems) as previously described ${ }^{40}$. Sections were immunolabeled with anti- $\alpha$ Syn sc-69977 (Santa Cruz, 1:200 dilution) in PBS and $1 \%(\mathrm{w} / \mathrm{v})$ BSA for $1 \mathrm{~h}$. After washing, sections were incubated with 12 $\mathrm{nm}$ gold-labeled goat anti-mouse IgG (Dianova, 1:30) for $0.5 \mathrm{~h}$ according to standard procedures. Cryosections were contrasted using a mixture of tungstosilicic acid hydrate (Fluka) and $2.5 \%$ polyvinyl alcohol (Sigma) as described in ${ }^{41}$. Cell sections were dried and viewed on a $90 \mathrm{kV}$ Zeiss 902A electron microscope (HeLa cells), or on a $200 \mathrm{kV}$ Tecnai FEG F20 electron microscope (RCSN-3 cells) equipped with Gatan 2k x 2k CCD cameras. 
Concentration measurements of $\alpha$ Syn in electroporated cells

To determine intracellular $\alpha$ Syn concentrations in the different in-cell NMR samples, we removed $\sim 10 \mu \mathrm{L}$ aliquots of electroporated cells and counted them on a haemocytometer. By knowing how many manipulated cells were available for the individual in-cell NMR experiments $\left(N_{\text {total }}\right)$, we first determined the absolute concentration of intracellular $\alpha$ Syn in each sample by Western blotting. To do so, we sedimented $1 \times 10^{6}$ cells and directly resuspended the cell pellet in $100 \mu \mathrm{L}$ of $1 \times$ Laemmli buffer. After boiling for $10 \mathrm{~min}$ at $95^{\circ} \mathrm{C}, 10,20$, or $30 \mu \mathrm{L}$ of the sample were loaded onto a SDS PAGE (i.e. $1-3 \times 10^{5}$ cells per lane). By running a dilution series of 10-400 ng of recombinant $\alpha$ Syn on the same gel, Western blotting with anti$\alpha$ Syn antibodies and back-calculation allowed us to determine the average amount of $\alpha$ Syn per cell. With $400 \mu \mathrm{M}$ of $\alpha$ Syn in the EPB, these concentrations were in the range of $0.1 \mathrm{fmol} / \mathrm{cell}(1.5 \mathrm{pg} / \mathrm{cell})$ for A2780 cells, $0.06 \mathrm{fmol} / \mathrm{cell}(0.8 \mathrm{pg} / \mathrm{cell})$ for HeLa cells, $0.03 \mathrm{fmol} / \mathrm{cell}(0.4 \mathrm{pg} /$ cell $)$ for RCSN-3 cells, $0.06 \mathrm{fmol} / \mathrm{cell}(0.8 \mathrm{pg} / \mathrm{cell})$ for B65 cells, and $0.07 \mathrm{fmol} / \mathrm{cell}(1.0 \mathrm{pg} / \mathrm{cell})$ for SK-N-SH cells.

To determine intracellular $\alpha$ Syn concentrations in molar terms, we measured individual cell volumes $\left(V_{\text {cell }}\right)$ with a CASY Model TT cell analyzer and a $60 \mu \mathrm{M}$ capillary (Roche). Values obtained were $1.1 \pm 0.6 \mathrm{pL}$ for A2780 cells, $2.9 \pm 0.5 \mathrm{pL}$ for HeLa cells, $0.8 \pm 0.4 \mathrm{pL}$ for RCSN-3 cells, $2.3 \pm 1.3 \mathrm{pL}$ for B65 cells, and $0.6 \pm 0.3$ $\mathrm{pL}$ for SK-N-SH cells. By using these volumes and the absolute per-cell concentrations (fmol/cell) that we determined by Western blotting (see above), we delineated average molar concentrations of $\alpha$ Syn in the different cell types. 
The different cell types settled differently in the respective NMR tubes, which led to specific 'packing' volumes of the individual in-cell NMR samples. By knowing how many cells were loaded into the individual NMR tubes $\left(N_{\text {total }}\right)$ and after measuring the heights of the settled cell pellets in $\mathrm{mm}\left(h_{\text {pellet }}\right)$, we derived the number of cells within the dimensions of the receiver coil $\left(N_{\text {cell }}\right)$ with $N_{\text {cell }}=N_{\text {total }} / h_{\text {pellet }} \mathrm{x} 18$ (height of the receiver coil in $\mathrm{mm}$ ) for $h_{\text {pellet }}>18 \mathrm{~mm}$, and with $N_{\text {cell }}=N_{\text {total }}$ for $h_{\text {pellet }}$ $<18 \mathrm{~mm}$. To quantify the amounts of intracellular ${ }^{15} \mathrm{~N}$-labeled $\alpha$ Syn detected in the NMR receiver coil, we recorded ${ }^{15} \mathrm{~N}$-edited 1D SOFAST-HMQC spectra of $\alpha$ Syn in buffer, which we then compared to the effective amide-envelope signal intensities $\left(S_{\text {eff }}\right)$ of the corresponding in-cell NMR samples. We corrected for signal loss during the SOFAST-HMQC pulse sequence due to fast intracellular $R_{2}\left({ }^{l} H\right)$ relaxation (proton magnetization is on the transverse plane for $15 \mathrm{~ms}$ ) by assuming average $R_{2}$ $\left({ }^{l} \mathrm{H}\right)$ values of $15 \mathrm{~Hz}$ (in buffer) and $40 \mathrm{~Hz}$ (in cells), in agreement with experimental results (Extended Data Fig. 5). Intensity loss was calculated considering a single exponential decay for $R_{2}\left({ }^{l} H\right)$ relaxation (i.e. $\mathrm{I}(\mathrm{t})=\mathrm{I}(0) \times \exp \left(-\mathrm{t} \times R_{2}\left({ }^{l} H\right)\right)$. To obtain $\alpha$ Syn concentrations based on measured 1D amide-envelope signals $\left(S_{\text {eff }}\right)$, we applied a correction factor $\left(F_{\text {corr }}\right)$ as $\mathrm{I}(\mathrm{t})_{\text {buffer }} / \mathrm{I}(\mathrm{t})_{\text {cell }}=\exp (-0.015 \times 15) / \exp (-0.015 \times 40)=$ 1.45 , with which we determined NMR-derived intracellular concentrations of $\alpha$ Syn as $[\alpha \mathrm{Syn}]_{\mathrm{cell}}=S_{\text {eff }} \times 1.45 / N_{\text {cell }} / V_{\text {cell }}$.

Leakage and cell viability tests on electroporated cells

Each electroporated cell sample was additionally tested for viability and $\alpha$ Syn leakage (either after the respective in-cell NMR experiments or at selected time points after $\alpha$ Syn delivery). To do so, in-cell samples were gently resuspended in the excess 
volume of medium present above them and transferred into $1.5 \mathrm{~mL}$ Eppendorf tubes. After centrifugation $(200 \times \mathrm{g})$ for $3 \mathrm{~min}$, we recorded $1 \mathrm{D}$ and/or $2 \mathrm{D}$ NMR experiments on the resulting supernatants with acquisition settings and parameters identical to the ones used for the actual in-cell NMR experiments. Cell viability was assessed by Trypan Blue (0.2\% (w/v) Sigma) staining. Stained (non-viable) and unstained (viable) cells were counted on a haemocytometer. Protein leakage was tested by comparative Western blotting of sample supernatants and cell lysates. For lysate preparation, $\sim 2 \times 10^{6}$ cells were washed in $1 \mathrm{~mL}$ PBS and sedimented by centrifugation at $200 \times \mathrm{g}$ for $6 \mathrm{~min}$, at $25^{\circ} \mathrm{C}$. Cells were lysed in $50 \mu \mathrm{L}$ RIPA buffer (50 mM Tris, $150 \mathrm{mM} \mathrm{NaCl}, 0.1 \%$ SDS, $0.5 \%$ Na-deoxycholate, $1 \% \mathrm{NP} 40,1 \times$ Complete Protease inhibitor (Roche) and $1 \times$ PhosSTOP phosphatase inhibitor cocktail (Roche), $\mathrm{pH}$ 7.0) and water bath sonication. The lysate was cleared by centrifugation at $16,800 \times \mathrm{g}$, for $30 \mathrm{~min}$, at $4{ }^{\circ} \mathrm{C}$ and the soluble fraction collected. Total protein concentration was determined with a Bradford assay (averaging 4.5-5 $\mathrm{mg} / \mathrm{mL}$ ) and $20 \mu \mathrm{g}$ of protein (per lane) was applied onto SDS-PAGE for Western blotting.

\section{Reference and in-cell NMR experiments}

Suspensions of electroporated and recovered cells were transferred into 3, 4, or $5 \mathrm{~mm}$ (diameter) Shigemi tubes without plungers, depending on the final cell numbers. Cells were settled into the receiver-coil volume by gentle sedimentation with a hand-cranked centrifuge. The height of the sedimented cell slurry in the respective NMR tubes was measured with a ruler to calculate the number of manipulated cells within the receiver-coil volume (see above). 
All in-cell NMR and reference experiments were recorded on a $750 \mathrm{MHz}$ Bruker Avance spectrometer equipped with a cryogenically cooled triple resonance ${ }^{1} \mathrm{H}\left\{{ }^{13} \mathrm{C} /{ }^{15} \mathrm{~N}\right\}$ TCI probe. In-cell NMR experiments were performed on at least two independent samples. Unless stated otherwise, NMR spectra were acquired at $10{ }^{\circ} \mathrm{C}$. SOFAST-HMQC $^{42}$ or L-HSQC pulse sequences ${ }^{43}$ were used as indicated. SOFASTHMQC pulse sequences were chosen for $\alpha$ Syn in RCSN-3, B65 and HeLa cells. LHSQC pulse sequences were used for $\alpha$ Syn in A2780 and SK-N-SH cells. The underlying rationale was to use SOFAST-HMQC experiments for samples with low amounts of ${ }^{15} \mathrm{~N}$ isotope-enriched $\alpha$ Syn, and L-HSQC experiments for samples with higher amounts of isotope-enriched protein. Thresholds for satisfactory signal-tonoise ratios are lower in SOFAST-HMQC experiments, but relaxation during ${ }^{15} \mathrm{~N}$ chemical shift evolution is faster, which gives rise to lower resolution. ${ }^{15} \mathrm{~N}$-edited 1D NMR experiments to determine $\alpha$ Syn amide envelope profiles, and $2 \mathrm{D}{ }^{1} \mathrm{H}^{-15} \mathrm{~N}$ SOFAST-HMQC experiments were recorded with interscan delays of $60 \mathrm{~ms}$, using proton $90^{\circ}$ polychromatic PC9 pulses of $2400 \mu$ s and $180^{\circ}$ refocusing band-selective pulses with uniform response and phase (REBURP) of $1600 \mu \mathrm{s}$, both centered at a proton frequency of 8.7 p.p.m.. ${ }^{15} \mathrm{~N}$-decoupling during acquisition periods was accomplished with the Waltz-16 sequence at $1.25 \mathrm{kHz}$. 1D and $2 \mathrm{D}{ }^{1} \mathrm{H}^{15}{ }^{15} \mathrm{~N}-\mathrm{HSQC}$ experiments were recorded with interscan delays of $200 \mathrm{~ms}$, using selective E-BURP2 $90^{\circ}$ pulses of $1800 \mu \mathrm{s}$, and REBURP $180^{\circ}$ pulses of $1800 \mu$ s centered at 8.7 p.p.m.. The Waltz-16 sequence was used for ${ }^{15} \mathrm{~N}$-decoupling during acquisition periods. 1D ${ }^{1} \mathrm{H}_{-}{ }^{15} \mathrm{~N}$ SOFAST-HMQC spectra were recorded with 4096 scans and 1024 complex points. 1D ${ }^{1} \mathrm{H}-{ }^{15} \mathrm{~N}$ L-HSQC experiments were recorded with 256 scans and 2048 complex points (16.6 p.p.m. ${ }^{1} \mathrm{H}$ sweep-widths in both cases). $2 \mathrm{D}{ }^{1} \mathrm{H}^{-}{ }^{15} \mathrm{~N}$ NMR 
experiments were acquired with either 256, 512, 1024 or 2048 scans, as indicated, 1024 complex points for SOFAST-HMQC spectra and 2048 complex points for LHSQC spectra, (16.6 p.p.m. ${ }^{1} \mathrm{H}$ sweep-widths and zero-filling to 4096 points), and 128, 256 or 512 complex points for ${ }^{15} \mathrm{~N}$ (26 p.p.m. ${ }^{15} \mathrm{~N}$ sweep-widths, zero-filling to 1024 points). All spectra were initially processed with Topspin 3.1 (Bruker). Sine bell apodization was used for both dimensions for SOFAST-HMQC spectra. No apodization was applied to L-HSQC spectra. Spectra were analyzed with iNMR 3.6.3 and Sparky ${ }^{44}$.

Reference experiments of isolated $\alpha$ Syn were acquired with $5-100 \mu \mathrm{M}$ of $\mathrm{N}$ terminally acetylated $\alpha$ Syn, or unmodified protein (where indicated) in NMR buffer at $\mathrm{pH} 6.4,6.9$ or 7.4 , supplemented with $10 \% \mathrm{D}_{2} \mathrm{O}$. In all cases, reference NMR spectra were recorded under identical conditions as the respective in-cell NMR experiments, including identical tube diameters, pulse sequences, spectrometer settings and general acquisition parameters. Mean weighted chemical shift differences (MWCS) of in-cell $\alpha$ Syn signals were determined with respect to reference NMR spectra of N-terminally acetylated $\alpha$ Syn and calculated as $\Delta \delta=\left[\left(\Delta \delta_{1 \mathrm{H}}\right)^{2}+\right.$ $\left.\left(\Delta \delta_{15 \mathrm{~N}} * 0.2\right)^{2}\right]^{1 / 2}$ (in p.p.m.) for each non-proline residue (missing values indicate resonances that were not analyzed due to spectral overlap). 3D HNCACB experiments on ${ }^{15} \mathrm{~N}-{ }^{13} \mathrm{C}$ labeled Ac- $\alpha$ Syn and unmodified protein were used to determine $\mathrm{C} \alpha, \mathrm{C} \beta$ chemical shift values and deviations from random coil according to ${ }^{45}$ and as input for calculating secondary structure propensity (SSP) scores following the procedure by Marsh et al. ${ }^{46}$.

To prepare lysates of in-cell NMR samples, cells were sedimented for $3 \mathrm{~min}$ at $200 \times \mathrm{g}$ and $100 \mu \mathrm{L}$ of supernatant was added back to resuspend the pellet. The slurry 
was transferred into a $1.5 \mathrm{~mL}$ Eppendorf tube and lysed by five freeze-thaw cycles on a methanol-ice bath followed by three rounds of water bath sonication for $20 \mathrm{~s}$. Lysates were centrifuged at $16,800 \times \mathrm{g}$ at $4{ }^{\circ} \mathrm{C}$ and soluble fractions collected and transferred to the original NMR tubes. 1D/2D NMR spectra were recorded with identical spectrometer and acquisition settings as for the intact in-cell NMR samples. Western blotting after SDS-PAGE separation of soluble and insoluble lysate fractions was used to confirm the presence and intactness of $\alpha$ Syn. For native PAGE separation of in-cell NMR sample lysates, commercial pre-cast gels, running and sample buffers (BioRad) were used with the following reference aggregates of $\alpha$ Syn: $\mathrm{H}_{2} \mathrm{O}_{2} /$ Cytochrome c (Cyt c)-mediated low- (LMW) and high-molecular weight (HMW) aggregates of $\alpha$ Syn prepared as described in ${ }^{47}$. In brief, LMW and HMW aggregates were produced by covalent di-tyrosine cross-linking of N-terminally acetylated $\alpha$ Syn via incubation with equimolar amounts of Cyt $c$ and a 2- or 200-fold excess of $\mathrm{H}_{2} \mathrm{O}_{2}$ for 30 min at $25{ }^{\circ} \mathrm{C}$, respectively. Excess $\mathrm{H}_{2} \mathrm{O}_{2}$ was removed on a Superdex 75 (GE, Healthcare) and purified aggregates were flash-frozen and stored at $-80{ }^{\circ} \mathrm{C}$ until use. $\alpha$ Syn amyloid fibrils were obtained by stirring $100 \mu \mathrm{L}$ of $50 \mu \mathrm{M} N-$ terminally acetylated $\alpha$ Syn in $50 \mathrm{mM}$ sodium phosphate, $150 \mathrm{mM} \mathrm{NaCl}, \mathrm{pH} 7.5$, at 200 r.p.m. and $37^{\circ} \mathrm{C}$ for 24 h. Formation of mature amyloid fibrils was monitored by Thioflavin-T (ThT) staining and transmission electron microscopy according to ${ }^{38}$. LMW and HMW aggregates and mature amyloid fibrils were shortly vortexed before use. 
Intensity profile and NMR relaxation measurements in cells and artificially crowded solutions

NMR experiments in artificially crowded in vitro solutions were acquired with $100 \mu \mathrm{M}{ }^{15} \mathrm{~N}$ isotope-enriched N-terminally acetylated $\alpha$ Syn in NMR buffer, at $\mathrm{pH} 6.4$ and $\mathrm{pH} 7.4,6 \% \mathrm{D}_{2} \mathrm{O}$, in the presence of either $200 \mathrm{~g} / \mathrm{L} \mathrm{BSA}$ (Sigma), $200 \mathrm{~g} / \mathrm{L}$ Ficoll 70 (Sigma), $20 \%$ (w/v) glycerol (Merck), $10 \mathrm{~g} / \mathrm{L}$ lysozyme (AppliChem), $8 \mathrm{M}$ urea (Sigma), or small unilamellar vesicles (SUVs) reconstituted from pig brain polar lipids (Avanti, see below). Intensity ratios $\left(\mathrm{I} / \mathrm{I}_{0}\right)$ of reference $\left(\mathrm{I}_{0}\right)$ and in-cell or crowded solution NMR signal intensities (I) were determined by extracting wellresolved cross-peak intensities from the respective $2 \mathrm{D}{ }^{1} \mathrm{H}_{-}{ }^{15} \mathrm{~N}$ NMR spectra. Nitrogen $\left({ }^{15} \mathrm{~N}\right)$ - and proton $\left({ }^{1} \mathrm{H}\right)$-relaxation experiments were acquired with pulse sequences based on those described by Farrow et al. ${ }^{48} . R_{l}, R_{2}$ and nOe data were obtained with 1024 complex points in the ${ }^{1} \mathrm{H}$ dimension, (16.6 p.p.m. ${ }^{1} \mathrm{H}$ sweep-widths, zero-filling to 4096 points), and with 128 or 256 complex points in the ${ }^{15} \mathrm{~N}$ dimension (26 p.p.m. ${ }^{15} \mathrm{~N}$ sweep-widths, zero-filling to 1024 points) in the case of mammalian in-cell NMR experiments and in vitro reference samples, respectively.

${ }^{15} \mathrm{~N} R_{l}$ rates were measured with 8 scans and relaxation delays set to 40,100 , $200,300,500,700,900$, and $1200 \mathrm{~ms}$ for reference and crowded in vitro samples. $R_{l}$ relaxation rates were determined at $\alpha$ Syn concentrations of $S_{\text {eff }} \sim 17 \mu \mathrm{M}, R_{2}\left({ }^{1} H\right)$ corrected $\sim 25 \mu \mathrm{M}$, and $[\alpha \mathrm{Syn}]_{\text {cell }}$ of $\sim 80 \mu \mathrm{M}$ in A2780 and $\sim 120 \mu \mathrm{M}$ in SK-N-SH cells, with 64 scans and relaxation delays set to 40, 100, 200, 300, 500 and $900 \mathrm{~ms}$. ${ }^{15} \mathrm{~N} R_{2}$ relaxation rates were measured with Carr-Purcell-Meiboom-Gill (CPMG) pulse trains with 16 scans and relaxation delays set to 20, 40, 80, 120, 200, 300, 400 and $600 \mathrm{~ms}$ for reference and crowded in vitro samples, and with delays set to 20,50, 80, 120 and $200 \mathrm{~ms}$ for in-cell NMR samples $\left(S_{\text {eff }} \sim 17 \mu \mathrm{M}, R_{2}\left({ }^{l} H\right)\right.$-corrected $\sim 25 \mu \mathrm{M}$ and 
$[\alpha \mathrm{Syn}]_{\mathrm{cell}} \sim 80 \mu \mathrm{M}$ in $70 \times 10^{6} \mathrm{~A} 2780$ and $120 \mu \mathrm{M}$ in $100 \times 10^{6} \mathrm{SK}-\mathrm{N}-\mathrm{SH}$ cells $)$. CPMG spectra with the 20 ms relaxation delay were recorded twice. Steady-state ${ }^{1} \mathrm{H}$ ${ }^{15} \mathrm{~N}$ nOe data were obtained from analyzing the ratios of peak intensities in paired NMR spectra recorded with and without initial periods $(3 \mathrm{~s})$ of proton saturation during recycling delays, with 16 scans for reference and crowded in vitro samples, and with 64 scans for in-cell NMR specimens $\left(S_{\text {eff }} \sim 20 \mu \mathrm{M}, R_{2}\left({ }^{1} H\right)\right.$-corrected $\sim 30$ $\mu \mathrm{M}$, and $[\alpha \mathrm{Syn}]_{\mathrm{cell}} \sim 100 \mu \mathrm{M}$ in A2780 and $\sim 140 \mu \mathrm{M}$ in SK-N-SH cells).

Proton $R_{2}\left({ }^{1} H\right)$ relaxation rates were measured using a pulse sequence described by Clore and co-workers ${ }^{49}$. Selective proton pulses were used to avoid artifacts from water magnetization as described in ${ }^{50}$. A half-Gaussian $90^{\circ}$ pulse of 2 $\mathrm{ms}$, and soft square pulses of $400 \mu \mathrm{s}$, or $1 \mathrm{~ms}$ were employed for water selective excitation (centered at 4.7 p.p.m.), and E-BURP2 $90^{\circ}$ pulses of $1800 \mu$ s and REBURP $180^{\circ}$ pulses of $1800 \mu$ s were used for amide-selective excitation (centered at 8.7 p.p.m.). Proton $R_{2}\left({ }^{l} H\right)$ relaxation measurements were recorded with relaxation delays set to $3,8,13,18,28,48,78,108$ and $158 \mathrm{~ms}$ for reference and crowded in vitro samples, and with $3,5.5,8,13,18$ and $28 \mathrm{~ms}$ for in-cell NMR samples $\left(S_{\text {eff }} \sim 14 \mu \mathrm{M}\right.$, $R_{2}\left({ }^{1} H\right)$-corrected $\sim 20 \mu \mathrm{M}$, and $[\alpha \operatorname{Syn}]_{\text {cell }} \sim 70 \mu \mathrm{M}$ in $70 \times 10^{6} \mathrm{~A} 2780$ and $[\alpha \mathrm{Syn}]_{\text {cell }}$ $\sim 100 \mu \mathrm{M}$ in $100 \times 10^{6} \mathrm{SK}-\mathrm{N}-\mathrm{SH}$ cells). Spectra with $3 \mathrm{~ms}$ delays were recorded twice in each set of the relaxation experiments.

CLEANEX-PM experiments were used to obtain amide proton exchange rates for reference and crowded in vitro samples, at $\mathrm{pH} 7.4^{51,52}$, and employing the pulse sequence by Hwang et al. ${ }^{52}$. CLEANEX mixing times of 5, 10, 15 and $20 \mathrm{~ms}$ were used for N-terminally acetylated reference $\alpha$ Syn sample, 10, 20, 30, and $40 \mathrm{~ms}$ for Nterminally acetylated $\alpha$ Syn in BSA- and lysozyme-crowded solutions and urea, and 
$15,30,45$ and $60 \mathrm{~ms}$ for N-terminally acetylated $\alpha$ Syn in glycerol and Ficoll. A spinlock power of $5 \mathrm{kHz}$ was employed in all cases. Reference signal intensities $\left(\mathrm{I}_{0}\right)$ were obtained with standard fast-HSQC pulse sequences and WATERGATE solvent suppression. To determine amide proton exchange constants, we fitted signal intensity build-up curves of well resolved and unambiguously assigned NMR cross-peaks against the different mixing times with previously reported equations ${ }^{51,52}$ in GraphPad Prism. Residue resolved amide proton exchange rates are available in Source Data.

Analysis of $\alpha$ Syn dynamics in cells and artificially crowded solutions

Residue-specific ${ }^{15} \mathrm{~N} R_{1^{-}}$and $R_{2^{-}}$, as well as ${ }^{1} \mathrm{H} R_{2}\left({ }^{1} H\right)$-relaxation rates were determined by extracting cross-peak intensities of the individual relaxation experiments and by fitting intensity reductions at longer relaxation delays to monoexponential decays in GraphPad Prism. Because of faster water-amide proton exchange in disordered proteins, we delineated ${ }^{15} \mathrm{~N} R_{2}$ relaxation rates by taking amide proton chemical exchange contributions into account (see above), and by fitting to a multi-exponential decay function that included the $\mathrm{H}-\mathrm{N}$ exchange constant according to Kim et al. ${ }^{53}$.

Backbone amide relaxation data were analyzed with ModelFree 4.15 ${ }^{54,55}$ and a model-independent interpretation approach proposed by Poulsen and co-workers ${ }^{56}$. Using ModelFree, we fitted $S_{\text {slow }}{ }^{2}, S_{\text {fast }}{ }^{2}, \tau_{e}$ and a global correlation time $\tau_{m}$ to residues $1-140$ of N-terminally acetylated $\alpha$ Syn, based on the measured ${ }^{15} \mathrm{~N} R_{1}, R_{2}$ and ${ }^{1} \mathrm{H}-{ }^{15} \mathrm{~N}$ nOe values obtained from NMR relaxation experiments under pure reference conditions, or in glycerol-, Ficoll-, or urea-containing in vitro solutions. For NMR relaxation experiments on samples containing small unilamellar vesicles (SUVs, see below), BSA, or lysozyme, as well as intact cells, we initially fitted $S_{\text {slow }}{ }^{2}, \tau_{e}$ and a 
global correlation time $\tau_{m}$ to the measured ${ }^{15} \mathrm{~N} R_{l}$ and ${ }^{1} \mathrm{H}^{-}{ }^{15} \mathrm{~N}-\mathrm{nOe}$ values. We

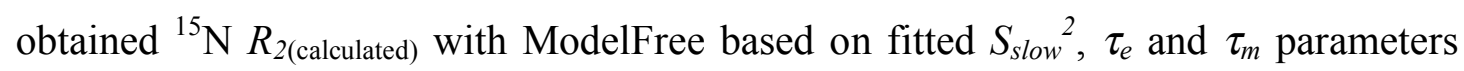
(with a fixed $S_{\text {fast }}{ }^{2}=0.85$, according to results in crowded media). We then defined the exchange term $\left(R_{e x}\right)$ as a floating parameter that, when included, enabled better fitting of $\alpha$ Syn regions with five or more consecutive residues exhibiting ${ }^{15} \mathrm{~N} R_{2 \text { (calculated) }}$ values lower than the experimentally determined ${ }^{15} \mathrm{~N} R_{2 \text { (measured). Thus, we effectively }}$ employed two fitting models in the ModelFree calculations based on measured ${ }^{15} \mathrm{~N}$ $R_{1}, R_{2}$ and ${ }^{1} \mathrm{H}-{ }^{15} \mathrm{~N}-\mathrm{nOe}$ values: First, we fitted $S_{\text {slow }}{ }^{2}, S_{\text {fast }}{ }^{2}, \tau_{e}$ and a global $\tau_{m}$ (with

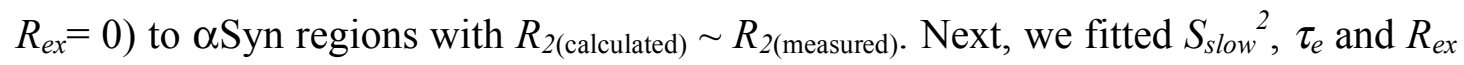
for $\alpha$ Syn regions with $R_{2 \text { (calculated) }} \neq R_{2 \text { (measured) }}$ using a fixed $S_{\text {fast }}{ }^{2}$ and global $\tau_{m}$ (i.e., average of non- $R_{e x}$ regions). In BSA-crowded solutions and in A2780 and SK-N-SH cells, these regions included residues 1-68 and 90-140. In the presence of lysozyme, these were residues 87-140. With SUVs, these were residues 1-104. Residue-specific correlation time averages $\left(<\tau_{c}>\right)$ were calculated as $\left\langle\tau_{c}\right\rangle=S_{f}^{2} S_{s}^{2}\left(\tau_{m}-\tau_{e}\right)+S_{f}^{2} \tau_{e}{ }^{56}$.

\section{aSyn membrane binding}

Small unilamellar vesicles (SUVs) were prepared from pig brain polar lipid extracts (Avanti) as described in ${ }^{57}$. Briefly, extract powder was weighted and solubilized to final concentrations of 16 or $3.2 \mathrm{mg} / \mathrm{mL}$ in NMR buffer (pH 6.4 or 7.4) and vortexed for $30 \mathrm{~min}$ at $25{ }^{\circ} \mathrm{C}$. After 5 freeze-thaw cycles on dry ice and incubation in a water bath $\left(37^{\circ} \mathrm{C}\right)$, samples were sonicated (Bandelin Sonoplus) at 30 $\%$ power for $20 \mathrm{~min}$ at $4{ }^{\circ} \mathrm{C}$ and centrifuged at $16,800 \times \mathrm{g}$ for $10 \mathrm{~min}$. Resulting SUVs of $65 \mathrm{~nm}$ diameter (see below for dynamic light scattering experiments) were stored at $4{ }^{\circ} \mathrm{C}$ and used within 2 days. Due to the heterogeneity of pig brain polar lipids in 
these extracts, $\alpha$ Syn:lipid ratios for NMR sample preparations were calculated assuming an average lipid mass of $800 \mathrm{Da}$. For experiments with saturating amounts of SUVs, a 400 -fold molar excess $(16 \mathrm{mg} / \mathrm{mL})$ of vesicles was added to $50 \mu \mathrm{M}{ }^{15} \mathrm{~N}$ isotope-enriched, N-terminally acetylated $\alpha$ Syn. For experiments with sub-saturating amounts of SUVs, a 80 -fold molar excess of vesicles $(3.2 \mathrm{mg} / \mathrm{mL})$ was added to 100 $\mu \mathrm{M}$ of ${ }^{15} \mathrm{~N}$ isotope-enriched, N-terminally acetylated $\alpha$ Syn. SOFAST-HMQC, LHSQC, ${ }^{15} \mathrm{~N}$ - and ${ }^{1} \mathrm{H}$-relaxation experiments were recorded at $10{ }^{\circ} \mathrm{C}$ at sub-saturating amounts of SUVs and at $30^{\circ} \mathrm{C}$ at saturating amounts of SUVs. NMR signal intensity ratios $\left(\mathrm{I} / \mathrm{I}_{0}\right)$ were determined in the presence $(\mathrm{I})$ or absence $\left(\mathrm{I}_{0}\right)$ of SUVs as outlined above.

QSyn paramagnetic relaxation enhancement (PRE) measurements and analysis

$\alpha$ Syn mutants Q24C, S42C, N122C, Q24C-N122C and S42C-N122C were used to measure in-cell and in vitro PRE effects. Gd(III)- and Lu(III)-DOTA tagged $\mathrm{N}$-terminally acetylated $\alpha$ Syn was prepared by reacting the corresponding single, or double cysteine mutants $(800 \mu \mathrm{M}, 200 \mathrm{mM}$ ammonium acetate buffer, $\mathrm{pH}$ 6.5) with a 3-fold excess of the DOTA-maleimide cage (Chematech) for $3 \mathrm{~h}$ at $40{ }^{\circ} \mathrm{C}$. Maleimide coupling to the respective sulfhydryl groups produces stable thioether bonds that withstand the reducing environment of the cytoplasm ${ }^{26}$. A 9-fold excess of $\mathrm{GdCl}_{3}$ or $\mathrm{LuCl}_{3}$ (Sigma) was added to the respective samples and reacted for $1 \mathrm{~h}$ at $40{ }^{\circ} \mathrm{C}$. Removal of excess unreacted DOTA-maleimide, $\mathrm{GdCl}_{3}$ and $\mathrm{LuCl}_{3}$, as well as buffer exchange to $200 \mathrm{mM}$ ammonium acetate $\mathrm{pH} 5.5$, was achieved by gel filtration. Samples were further purified and buffer exchanged to $20 \mathrm{mM}$ sodium phosphate, 150 $\mathrm{mM} \mathrm{NaCl}, \mathrm{pH} 7.0$, via a second gel filtration step. SDS-PAGE, size exclusion 
chromatography and dynamic light scattering (DLS) were used to confirm $\alpha$ Syn purity and monodispersity. Diameters of unmodified, or the differently DOTA tagged versions of N-terminally acetylated $\alpha$ Syn were determined on a Malvern Zetasizer Nano DLS machine with a $633 \mathrm{~nm}$ laser. Measurements were performed at $25^{\circ} \mathrm{C}$ in 3 $\times 3 \mathrm{~mm}$ cuvettes, with protein concentrations of $50 \mu \mathrm{M}$ (and SUV concentrations of 16 or $3.2 \mathrm{mg} / \mathrm{mL}$ ). Measurements were performed after centrifugation at $16,800 \times \mathrm{g}$ for $10 \mathrm{~min}$. Volume weighted analyses of scattered light were derived with the Malvern DTS software. To exclude epitope interference of the Gd(III)- and Lu(III)DOTA moieties on tagged $\alpha$ Syn, additional quality tests were done by Western blotting with a primary antibody against the N-terminus of the protein (ab51252, Abcam, 1:1,000 dilution).

For intramolecular PRE measurements in A2780 and SK-N-SH cells, Gd(III)DOTA, or Lu(III)-DOTA was coupled to uniformly ${ }^{15} \mathrm{~N}$ isotope-enriched $\mathrm{N}$ terminally acetylated $\alpha$ Syn via residues 42 (S42C) or 122 (N122C). Mixtures of paramagnetic Gd(III)-DOTA $\alpha$ Syn $(280 \mu \mathrm{M})$ and diamagnetic Lu(III)-DOTA $\alpha$ Syn $(120 \mu \mathrm{M})$ were delivered into cells, the latter serving as the internal reference in the subsequent analysis routines (see below). Delivery efficiencies and intracellular $\alpha$ Syn concentrations were delineated based on experiments with untagged and Lu(III)DOTA $\alpha$ Syn and estimated to be $[\alpha \operatorname{Syn}]_{\text {cell }} \sim 80 \mu \mathrm{M}$ with $40 \times 10^{6}$ A2780 and $\sim 120$ $\mu \mathrm{M}$ with $50 \times 10^{6} \mathrm{SK}-\mathrm{N}-\mathrm{SH}$ cells $(4 \mathrm{~mm}$ Shigemi tubes). For intramolecular PRE measurements in artificially crowded in vitro solutions, $100 \mu \mathrm{M}$ of $\mathrm{N}$-terminally acetylated $\alpha$ Syn was analyzed in NMR buffer in the presence of the indicated amounts of crowding agents, at $\mathrm{pH} 6.4$ and $\mathrm{pH}$ 7.4. Reference NMR experiments of 
the isolated protein were recorded with $100 \mu \mathrm{M} \alpha$ Syn in NMR buffer at $\mathrm{pH} 6.4$ and $\mathrm{pH}$ 7.4. PRE results obtained for glycine residues showed a strong $\mathrm{pH}$ dependency, which is likely caused by the high water-amide proton exchange rates of these residues. Therefore, we did not include glycine PRE values in our analysis.

For intermolecular PRE measurements in A2780 cells, paramagnetic Gd(III)DOTA was coupled to $300 \mu \mathrm{M}$ of non isotope-enriched N-terminally acetylated $\alpha$ Syn via residues $42(\mathrm{~S} 42 \mathrm{C})$ or $122(\mathrm{~N} 122 \mathrm{C})$ and added to equal volumes of $300 \mu \mathrm{M}$ unmodified, ${ }^{15} \mathrm{~N}$-isotope enriched and $\mathrm{N}$-terminally acetylated $\alpha$ Syn (final concentration of $\alpha$ Syn $300 \mu \mathrm{M})$. These mixtures were delivered into cells following the original electroporation protocol. Total intracellular $\alpha$ Syn concentration $[\alpha \operatorname{Syn}]_{\text {cell }}$ $\sim 120 \mu \mathrm{M}$ (isotope-enriched $\alpha \operatorname{Syn} \sim 60 \mu \mathrm{M}$ ) in $40 \times 10^{6}$ A2780 cells (4 mm Shigemi tubes). For intermolecular PRE measurements in artificially crowded in vitro solutions, $50 \mu \mathrm{M}$ of non isotope-enriched, N-terminally acetylated $\alpha$ Syn coupled to Gd(III)-DOTA at positions 42 (S42C), or 122 (N122C) and equimolar amounts of ${ }^{15} \mathrm{~N}$ isotope-enriched, N-terminally acetylated $\alpha$ Syn were analyzed in the presence of the indicated amounts of crowding agents, at $\mathrm{pH} 6.4$ and $\mathrm{pH}$ 7.4. Reference PRE experiments of isolated $\alpha$ Syn were recorded in the absence of crowding agents.

To determine residue-resolved PRE effects we acquired $2 \mathrm{D}{ }^{1} \mathrm{H}-{ }^{15} \mathrm{~N}$ L-HSQC spectra of S42C- and N122C-coupled Gd(III)-DOTA, or Lu(III)-DOTA N-terminally acetylated $\alpha$ Syn as the paramagnetic $\left(I_{\text {para }}\right)$ or diamagnetic $\left(I_{\text {dia }}\right)$ species, respectively. 2D NMR spectra of reference and crowded in vitro samples were recorded with 32 scans and $2048\left({ }^{1} \mathrm{H}\right) \times 512\left({ }^{15} \mathrm{~N}\right)$ complex points (sweep-widths 16.6 p.p.m. $\left({ }^{1} \mathrm{H}\right)$ and 26 p.p.m. $\left({ }^{15} \mathrm{~N}\right)$, zero-filling to 4096 and 1024 points, respectively). In-cell PRE 
measurements were performed with 1024 scans and $2048\left({ }^{1} \mathrm{H}\right) \times 128\left({ }^{15} \mathrm{~N}\right)$ complex points.

\section{PRE analysis and distance calculations}

PRE effects were quantified by measuring the cross-peak intensities of paramagnetic $\left(I_{\text {para }}\right)$ and diamagnetic $\left(I_{d i a}\right)$ N-terminally acetylated $\alpha$ Syn species. For the different in vitro conditions, we obtained these values from independent measurements of Gd(III)-DOTA $\left(I_{\text {para }}\right)$ - and Lu(III)-DOTA $\left(I_{\text {dia }}\right)$-, S42C- and N122Ctagged, N-terminally acetylated $\alpha$ Syn. For in-cell PRE experiments, we normalized the measured intensities of the $I_{\text {para }}$ states to the total amount of $\alpha$ Syn in the respective samples. Because residues in the vicinity of the paramagnetic Gd(III)-DOTA tag are broadened beyond detection, NMR signals originating from the $30 \%$ of diamagnetic Lu(III)-DOTA tagged $\alpha$ Syn in the mixture served as the quantitative internal standard, based on which absolute cross-peak intensities and residue-specific PRE effects were determined. Following the treatment by Battiste and Wagner ${ }^{58}$, we calculated the magnitudes of paramagnetic contributions to $\alpha$ Syn's transverse relaxation rates $\left(R_{2 \text { para }}\right)$ according to $\frac{I_{\text {para }}}{I_{\text {dia }}}=\frac{R_{2}\left({ }^{1} H\right) * \exp \left(R_{2 \text { para }} * t_{\text {INEPT }}\right)}{R_{2}\left({ }^{1} H\right)+\left(R_{2 \text { para }}\right)}$, with $t_{\text {INEPT }}$ $=10 \mathrm{~ms}$ and $R_{2}\left({ }^{1} \mathrm{H}\right)$ as the residue-specific proton relaxation rates determined previously. Assuming that $\mathrm{Gd}(\mathrm{III})-{ }^{1} \mathrm{H}$ vector fluctuation rates scale linearly with those of backbone N-H vectors and Gd(III)-DOTA complexes, we calculated $d$ as the residue-specific distance to the Gd(III)-DOTA tag using a simplified version of the Solomon-Bloembergen equation for electron-nucleus dipolar relaxation ${ }^{59}$, i.e. $\left\langle d^{-6}\right\rangle \approx \frac{R_{2 \text { para }}}{4 K \tau}$ with $\mathrm{K}=2.58 \times 10^{-31} \mathrm{~cm}^{6} . \mathrm{s}^{-2}$ for $\mathrm{Gd}(\mathrm{III})$, and $\tau$ as the total correlation 
time of the electron-nuclear interaction given by $\frac{1}{\tau}=\frac{1}{\tau_{c}}+\frac{1}{\tau_{\text {cage }}}+\frac{1}{\tau_{s}}$, with $\tau_{c}$ as the residue-specific correlation time calculated from NMR relaxation data, $\tau_{\text {cage }}$ as the Gd(III)-DOTA correlation time, and $\tau_{s}$ as the electron spin relaxation time. The correlation time of the free Gd(III)-DOTA complex was reported to be $\sim 500$ ps at 25 ${ }^{\circ} \mathrm{C}$, whereas its electron spin relaxation time has been reported to be $\sim 10$ ns on average $^{60-62}$. Hence, we evaluated $\tau_{\text {cage }}=\eta \times 2 n s$ with $\eta=\frac{\left\langle\tau_{c}\right\rangle}{\left\langle\tau_{c}\right\rangle_{\text {water }}}, \eta$ being the local viscosity as quantified by the average ratio between correlation times of $\mathrm{N}$-terminally acetylated $\alpha$ Syn in the different in vitro solutions, and in water containing only phosphate and $\mathrm{NaCl}$. We used $\tau_{s}=10 \mathrm{~ns}$. Varying the values for $\tau_{\text {cage }}$ and $\tau_{s}$ by a factor 2 had negligible effects on the calculated distances in the different environments.

Average radii of gyration $\left(R_{g}\right)$ were determined based on reported $\alpha$ Syn dimensions in buffer, independently derived with different biophysical methods including PRE and residual dipolar coupling (RDC)-, as well as NMR chemical shift (CSs)- and pulsed-field gradient (PFG) diffusion-measurements, and small angle $\mathrm{X}$ ray scattering (SAXS $)^{63,64}$. Given the excellent agreement of PRE buffer distances measured with $\alpha$ Syn samples spin-labeled at identical ${ }^{28}$, or nearby residue positions $^{27,63}$, and the similarity of residue-resolved PRE distance profiles recorded in buffer, cells and crowded solutions, we selected a representative set of buffer distances that we then compared to the same set of distances measured in cells and crowded solutions. From this, we derived sample-specific scaling factors $F_{\text {scale }}=$ 
$\sum d_{\text {cells or crowded solutions }} / \sum d_{\text {buffer }}$ with which we determined changes of global $\alpha$ Syn dimensions as $F_{\text {scale }} \times R_{g(\text { buffer }) \text {. }}$

Electron paramagnetic resonance (EPR) and double electron-electron resonance (DEER) experiments and analysis

Non isotope-enriched Q24C, S42C and N122C N-terminally acetylated $\alpha$ Syn, as well as Q24C-N122C, S42C-N122C N-terminally acetylated $\alpha$ Syn coupled to Gd(III)-DOTA were used for in-cell and reference EPR/DEER experiments. $125 \mu \mathrm{M}$ and $250 \mu \mathrm{M}$ of spin-labeled $\alpha$ Syn was electroporated into $20 \times 10^{6}$ A2780 cells $\left([\alpha \operatorname{Syn}]_{\text {cell }} \sim 20-50 \mu \mathrm{M}\right)$ along the original protocol (labeled 'low' and 'high' in Extended Data Fig. 9b). Data shown were obtained with in-cell EPR samples electroporated with $250 \mu \mathrm{M} \alpha$ Syn. After $5 \mathrm{~h}$ of recovery, manipulated cells were added to powder RPMI 1640 medium dissolved in $99.9 \% \mathrm{D}_{2} \mathrm{O}$ and washed $3 \times$ to remove non-internalized $\alpha$ Syn. Cells were incubated for an additional $10 \mathrm{~min}$ in a solution containing PBS in $\mathrm{D}_{2} \mathrm{O}$ and perdeuterated $\mathrm{d}_{8}$-glycerol $(8 / 2 \mathrm{v} / \mathrm{v})$ and washed 2 $\times$ with fresh aliquots of the same solution to remove any residual protein. The presence of $20 \% \mathrm{~d}_{8}$-glycerol proved essential for producing longer echo decays of Gd(III)-DOTA tagged $\alpha$ Syn and to preserve the intactness of cells during the freezing process (see next step). Finally, $\sim 2 \times 10^{6}$ cells were loaded into an EPR quartz capillary $(0.6 \mathrm{ID} \times 0.84 \mathrm{OD} \mathrm{mm})$, centrifuged to create a pellet and slowly frozen in isopropanol at $-80^{\circ} \mathrm{C}$. To check for residual protein in the supernatant, echo detected EPR spectra of the last wash were acquired to confirm absence of EPR signals. Reference EPR/DEER experiments were recorded on $50 \mu \mathrm{M}$ N-terminally acetylated 
$\alpha$ Syn with single Gd(III)-DOTA moieties at positions 24 (Q24C), 42 (S42C) and 122 (N122C), or with dual Gd(III)-DOTA tagged samples incorporated at positions 24 and 122 (Q24C-N122C), and 42 and 122 (S42C-N122C) in PBS- ${ }_{2} \mathrm{O}$ and $\mathrm{d}_{8}$-glycerol.

All EPR/DEER measurements were carried out on a home built W-band (95 $\mathrm{GHz}$ ) spectrometer ${ }^{65}$. Echo-detected (ED) EPR spectra were recorded at $10 \mathrm{~K}$ using $\pi / 2$ and $\pi$ pulse durations of $30 \mathrm{~ns}$ and $60 \mathrm{~ns}$, respectively, with an echo delay of 750 ns and a repetition time of $1 \mathrm{~ms}$. Echo decays were measured by Hahn echo decay experiments $(\pi / 2-\tau-\pi$ - $\tau$-echo) at the DEER observer frequency. The $\pi / 2$ and $\pi$ pulse durations were $15 \mathrm{~ns}$ and $30 \mathrm{~ns}$, respectively. Measurements were performed at $10 \mathrm{~K}$ with a repetition time of $750 \mu$ s and two-step phase cycling. DEER measurements were carried out at $10 \mathrm{~K}$ using the standard four-pulse DEER sequence ${ }^{66}$. The $\pi$ pump pulse ( $\left.\pi_{\text {pump }}\right)$ duration was $15 \mathrm{~ns}$ and the observer pulses $\left(\pi / 2_{\text {obs }}\right.$ and $\left.\pi_{\text {obs }}\right)$ were 15 and 30 ns respectively. Their frequency difference was $90 \mathrm{MHz}$, with the pump pulse set to the maximum of the EPR spectrum. This setup was chosen because it represents a good compromise between modulation depth, $\lambda$, and phase memory time. The repetition delay was $800 \mu \mathrm{s}$ and accumulation times were about $3 \mathrm{~h}$ for in vitro measurements and about $8 \mathrm{~h}$ for in-cell EPR samples. An eight-step phase cycle was employed: $\pi_{/ 2 \mathrm{obs}}:+\mathrm{x},-\mathrm{x},+\mathrm{x},-\mathrm{x},+\mathrm{x},-\mathrm{x},+\mathrm{x},-\mathrm{x} ; \pi_{\mathrm{obs}}:+\mathrm{x},+\mathrm{x},+\mathrm{x},+\mathrm{x},-\mathrm{x},-\mathrm{x},-\mathrm{x},-\mathrm{x} ; \pi_{\mathrm{pump}}$ : $+\mathrm{x},+\mathrm{x},-\mathrm{x},-\mathrm{x},+\mathrm{x},+\mathrm{x},-\mathrm{x},-\mathrm{x} ; \pi_{\mathrm{obs}}:+\mathrm{x},+\mathrm{x},+\mathrm{x}+\mathrm{x},+\mathrm{x},+\mathrm{x},+\mathrm{x}+\mathrm{x}$. The receiver phase cycle was,,,,,,,+-+-+-+- . Phase cycling was required to remove instrumental artifacts and to compensate for DC offsets. DEER data were analyzed with DeerAnalysis $2011^{67}$. Distance distributions were obtained using Gaussian model fits, because of the broad distance distributions. Batch-specific variations in the DEER traces of double Gd(III)-DOTA tagged $\alpha$ Syn in-cell EPR samples were observed due to differences in labeling efficiencies and concomitant changes in background decays. 
Same-batch samples were used whenever direct comparisons were made. Effective EPR concentrations of intracellular, single Gd(III)-DOTA tagged $\alpha$ Syn were estimated based on the slopes of in-cell DEER traces, in reference to slopes obtained on pure samples of known concentrations in buffer, measured under identical experimental conditions ${ }^{26}$.

\section{Supplementary References}

36. Ulmer, T. S. \& Bax, A. Comparison of structure and dynamics of micellebound human alpha-synuclein and Parkinson disease variants. J. Biol. Chem. 280, 43179-43187 (2005).

37. Johnson, M., Coulton, A. T., Geeves, M. A. \& Mulvihill, D. P. Targeted amino-terminal acetylation of recombinant proteins in E. coli. PLoS One 5, e15801 (2010)

38. Hoyer, W. et al. Dependence of alpha-synuclein aggregate morphology on solution conditions. J. Mol. Biol. 322, 383-393 (2002).

39. Lee, B. R. \& Kamitani, T. Improved immunodetection of endogenous alphasynuclein. PLoS One 6, e23939 (2011).

40. Tokuyasu, K. T. Immunochemistry on ultrathin frozen sections. Histochem. J. 12, 381-403 (1980).

41. Kargel, E. et al. Candida maltosa NADPH-cytochrome P450 reductase: Cloning of a full-length cDNA, heterologous expression in Saccharomyces cerevisiae and function of the $\mathrm{N}$-terminal region for membrane anchoring and proliferation of the endoplasmic reticulum. Yeast 12, 333-348 (1996). 
42. Schanda, P., Kupce, E. \& Brutscher, B. SOFAST-HMQC experiments for recording two-dimensional heteronuclear correlation spectra of proteins within a few seconds. J. Biomol. NMR 33, 199-211 (2005).

43. Pervushin, K., Vogeli, B. \& Eletsky, A. Longitudinal (1)H relaxation optimization in TROSY NMR spectroscopy. J. Am. Chem. Soc. 124, 1289812902 (2002).

44. Goddard, T. D. \& Kneller, D. G. SPARKY 3. University of California, San Francisco (2008).

45. Wishart, D. S. \& Sykes, B. D. Chemical shifts as a tool for structure determination. Methods Enzymol. 239, 363-392 (1994).

46. Marsh, J. A., Singh, V. K., Jia, Z. \& Forman-Kay, J. D. Sensitivity of secondary structure propensities to sequence differences between alpha- and gamma-synuclein: implications for fibrillation. Protein Sci. 15, 2795-2804 (2006).

47. Bayir, H. et al. Peroxidase mechanism of lipid-dependent cross-linking of synuclein with cytochrome C: protection against apoptosis versus delayed oxidative stress in Parkinson disease. J. Biol. Chem. 284, 15951-15969 (2009).

48. Farrow, N. A., Zhang, O., Forman-Kay, J. D. \& Kay, L. E. Characterization of the backbone dynamics of folded and denatured states of an SH3 domain. Biochemistry 36, 2390-2402 (1997).

49. Iwahara, J., Tang, C. \& Clore, G. M. Practical aspects of (1)H transverse paramagnetic relaxation enhancement measurements on macromolecules. $J$. Magn. Reson. 184, 185-195 (2007). 
50. Gobl, C., Madl, T., Simon, B. \& Sattler, M. NMR approaches for structural analysis of multidomain proteins and complexes in solution. Prog. Nucl. Mag. Reson. Spectrosc. 80, 26-63 (2014).

51. Croke, R. L., Sallum, C. O., Watson, E., Watt, E. D. \& Alexandrescu, A. T. Hydrogen exchange of monomeric alpha-synuclein shows unfolded structure persists at physiological temperature and is independent of molecular crowding in Escherichia coli. Protein Science 17, 1434-1445 (2008).

52. Hwang, T. L., van Zijl, P. C. M. \& Mori, S. Accurate quantitation of wateramide proton exchange rates using the Phase-Modulated CLEAN chemical EXchange (CLEANEX-PM) approach with a Fast-HSQC (FHSQC) detection scheme. J. Biomol. NMR 11, 221-226 (1998).

53. Kim, S., Wu, K. P. \& Baum, J. Fast hydrogen exchange affects 15 N relaxation measurements in intrinsically disordered proteins. J. Biomol. NMR 55, 249$256(2013)$.

54. Mandel, A. M., Akke, M. \& Palmer, A. G. Backbone dynamics of Escherichia coli Ribonuclease $\mathrm{H}$ - Correlations with structure and function in an active enzyme. J. Mol. Biol. 246, 144-163 (1995).

55. Palmer, A. G., Rance, M. \& Wright, P. E. Intramolecular motions of a zinc finger DNA-binding domain from Xfin characterized by proton-detected natural abundance $\mathrm{C} 12$ heteronuclear NMR spectroscopy. J. Am. Chem. Soc. 113, 4371-4380 (1991).

56. Modig, K. \& Poulsen, F. M. Model-independent interpretation of NMR relaxation data for unfolded proteins: the acid-denatured state of ACBP. $J$. Biomol. NMR 42, 163-177 (2008). 
57. Krylova, O. O., Jahnke, N. \& Keller, S. Membrane solubilisation and reconstitution by octylglucoside: comparison of synthetic lipid and natural lipid extract by isothermal titration calorimetry. Biophys. Chem. 150, 105-111 (2010).

58. Battiste, J. L. \& Wagner, G. Utilization of site-directed spin labeling and highresolution heteronuclear nuclear magnetic resonance for global fold determination of large proteins with limited nuclear Overhauser effect data. Biochemistry 39, 5355-5365 (2000).

59. Clore, G. M. \& Iwahara, J. Theory, practice, and applications of paramagnetic relaxation enhancement for the characterization of transient low-population states of biological macromolecules and their complexes. Chem. Rev. 109, 4108-4139 (2009).

60. Borel, A. et al. Towards the rational design of MRI contrast agents: Electron spin relaxation is largely unaffected by the coordination geometry of Gadolinium(III)-DOTA-Type complexes. Chemistry 14, 2658-2667 (2008).

61. Borel, A. et al. T-1e in four Gd3+ chelates: LODEPR measurements and models for electron spin relaxation. J. Phys. Chem. A 106, 6229-6231 (2002).

62. Kim, H. K., Lee, G. H., Kim, T. J. \& Chang, Y. M. Determination of Correlation Times of New Paramagnetic Gadolinium MR Contrast Agents by EPR and O-17 NMR. Bull. Korean Chem. Soc. 30, 849-852 (2009).

63. Schwalbe, M. et al. Predictive atomic resolution descriptions of intrinsically disordered hTau40 and alpha-synuclein in solution from NMR and small angle scattering. Structure 22, 238-249 (2014). 
64. Binolfi, A. et al. Interaction of alpha-synuclein with divalent metal ions reveals key differences: A link between structure, binding specificity and fibrillation enhancement. J. Am. Chem. Soc. 128, 9893-9901 (2006).

65. Goldfarb, D. et al. HYSCORE and DEER with an upgraded 95GHz pulse EPR spectrometer. J. Magn. Reson. 194, 8-15 (2008).

66. Pannier, M., Veit, S., Godt, A., Jeschke, G. \& Spiess, H. W. Dead-time free measurement of dipole-dipole interactions between electron spins. J. Magn. Reson. 213, 316-325 (2011).

67. Jeschke, G. et al. DeerAnalysis2006 - A comprehensive software package for analyzing pulsed ELDOR data. Appl. Magn. Reson. 30, 473-498 (2006). 